\title{
Fluvial responses to the Weichselian ice sheet advances and retreats: implications for understanding river paleohydrology and pattern changes in Central Poland
}

\author{
Piotr Weckwerth ${ }^{1}$
}

Received: 25 April 2017 / Accepted: 27 September 2017 / Published online: 23 October 2017

(c) The Author(s) 2017. This article is an open access publication

\begin{abstract}
The evolution of the fluvial systems during the Weichselian Pleniglacial in the Toruń Basin (Central Poland) was investigated through sedimentological investigation and paleohydraulic analysis. Within the basin, three fluvial cycles deposited after successive phases of the ice advance which took place 50, 28 and $20 \mathrm{ka}$ ago. Successions of four fluvial lithotypes characterize each fluvial formation, that are related to the paleoenvironmental changes (e.g., climate instability and changes in the river regime) which affected the channel hydraulics and morphology. The successions comprise river-style metamorphosis between high-energy sand-bed meandering rivers (lithotype M1), high-energy sand-bed braided rivers (lithotype B1), and medium-energy sand-bed braided rivers with either unit bars (lithotype B2) or compound bars (lithotype B3) reflects the maturity stage of sand-bed-braided river evolution in the basin. The assessment of the fluvial sedimentary environments enabled the construction of a quantitative model of the changes in the river channel pattern in relation to the climate oscillation. Both the paleohydrological controls and their sedimentary consequences are discussed in the article. Lithotypes M1 and $\mathrm{B} 1$ represent riverbed modeled under supercritical flow condition. Deposition of lithotype B2 corresponded to the river channel pattern transformation and was manifested by decreasing flow velocity (energy losses associated with bedform roughness and with the transportation of coarser particles). The flow velocity was generally greater in rivers
\end{abstract}

Piotr Weckwerth

pweck@umk.pl

1 Department of Geomorphology and Palaeogeography of Quaternary, Faculty of Earth Sciences, Nicolaus Copernicus University in Toruń, Lwowska 1, 87-100 Toruń, Poland of lithotype B3 and energy of sedimentary environment was more stable than during the deposition of lithotype B2.

Keywords River style changes - Sand-bed rivers · Climate oscillation $\cdot$ Weichselian glaciation $\cdot$ Poland

\section{Introduction}

Changes in fluvial styles throughout glacial-interglacial cycles were caused by combinations of periodic climate cooling and warming, ice sheet margin dynamics, fluctuations of the sea level and neotectonic movements (Kozarski 1983; Vandenberghe et al. 1994; Kasse et al. 1995; Huijzer and Vandenberghe 1998; Holbrook and Schumm 1999; Huisink 2000; Vandenberghe 2002, 2003; Van Huissteden and Kasse 2001; Houben 2003; Busschers et al. 2007; Erkens et al. 2009). The influence of the climate on fluvial processes has frequently been investigated by establishing variations in time of the pattern of river channels (a.o. Vandenberghe 1993, 1995, 2002, 2003; Mol 1997; Holbrook and Schumm 1999; Van Huissteden and Kasse 2001; Busschers et al. 2005, 2007, 2008; Starkel et al. 2007; Janssens et al. 2012; Meinsen et al. 2014); and by determining the changes in the textural and structural characteristics of fluvial sediments (a.o. Krzyszkowski 1996; Holbrook and Schumm 1999; Huisink 2000; Zieliński and Goździk 2001; Zieliński 2007). Changes of the riverbed morphology over the last glacial-interglacial transition have been found to be a direct result of spatial and temporal response to allogenic forcings (Schumm and Brakenridge 1987; Erkens et al. 2009). These forcings include climatic variations which influenced fluvial development by river regime changes, modification of the quality and extent of the vegetation cover in catchment and valley, the amount of the surface runoff and valley 
slope instability, limited infiltration due to permafrost, and of the type and intensity of the sediment supply to the river channel (e.g., aeolian sediments input and mass movements; a.o. Weckwerth and Pisarska-Jamroży 2015; Zieliński et al. 2015). Such climate-induced and vegetation-related transformation of river pattern (from a braided to a meandering system) were noted between the Late Pleniglacial and Late glacial periods in the alluvial reaches of mid-latitude European rivers (e.g., Vandenberghe et al. 1994; Kasse et al. 1995, 2005; Mol 1997; Busschers et al. 2007; Erkens et al. 2009; Janssens et al. 2012).

The principal indicators of the changes in the fluvial style are the changes in the morphology and the hydraulic parameters of the river channel (e.g., channel depth, width, river gradient), and the current energy (stream power). In the case of the Torun Basin during the Weichselian glaciation the river regime depended on the extent of the nearby southern sector of the Scandinavian ice sheet (Weckwerth 2010, 2013; Weckwerth and Chabowski 2013; Pisarska-Jamroży 2015; Pisarska-Jamroży et al. 2015; Woronko et al. 2015) as well as to semi-cyclic alternations of climatic cooling and warming (references in the previous paragraph).

Recognition of the types of river channel patterns and their changes requires the reconstruction of qualitative and quantitative characteristics of the fluvial environment. The existing models of the river channel pattern transformation are based mainly on the relationships that may occur between the flow competences (Leopold et al. 1964; Schumm 1977, 1985) and relationships between the stream power and the particle sizes of the transported sediments (Van den Berg 1995; Thorne 1997; Van den Berg and Bledsoe 2003; Anisimov et al. 2008). It is quite well understood that the hydraulic parameters of the rivers (flow depth, hydraulic gradient, channel morphology, water flow velocity and stream power) affect the development of bedforms, to which fluvial lithofacies correspond (Ashley 1990; Southard and Boguchwal 1990; Southard 1991). The associations of bedforms built fluvial lithotypes, which in turn are relevant to recognizing and discriminating river channel patterns developed under the equilibrium channel state (Leopold 1964; Langbein and Leopold 1966; Schumm 1977, 1985; Knighton 1984; Van den Berg 1995; Kleinhans and Van den Berg 2011), and relating them to former discharge regimes.

Several previous geomorphological and geological studies of Weichselian outwash plain fluvial successions have had the objective to quantitatively characterize these environments, as does this study (a.o. Zieliński and Van Loon 1999, 2003; Blažauskas et al. 2007; Pisarska-Jamroży 2015). These past studies, however, did not consider to analyse the river regimes and their hydraulic parameters, in addition to changes in the ice-sheet edge position, also changed coevally due to climate fluctuations in the case of fluvial successions which nowadays are buried under Weichselian tills in
Poland (Krzyszkowski 1996; Wysota et al. 1996; Zieliński and Goździk 2001; Wysota 2002; Molewski 2007; Zieliński 2007; Weckwerth 2011). Thus, this paper bridges between the two types of insights here, sedimentological interpretation of buried fluvial sequences, and between the Late Weichselian superficial insights about the climate-derived transformation of river channel pattern.

As the fluvial succession filling up the Pleistocene Torun Basin reaches a thickness of up to about $100 \mathrm{~m}$, sufficient data became available for the reconstruction of the changes of the fluvial system that occurred between the successive phases of advance of the Scandinavian ice sheet. Such a reconstruction is the main objective of the present study, which focuses on the evolution of the climate-induced fluvial processes. Consequently, this paper concentrates on the sedimentology and paleohydraulic reconstructions, whereas earlier studies have been carried out describing the chronological information the fluvial formations described at the same sites (Weckwerth et al. 2011, 2013; Weckwerth 2013). The study had the following approach: recognition of the fluvial lithotypes and interpretation of the depositional mechanisms involved, assessment of the quantitative and qualitative features of the fluvial environment and construction of a model of the changes in the river channel pattern during the Weichselian glaciation that shows its controlling paleohydrological parameters and the sedimentary consequences.

\section{Geological setting}

The Torun Basin, located in the north-central part of Poland, belongs to the eastern part of the Torun-Eberswalde icemarginal valley (Fig. 1). During the Weichselian glaciation, this basin was fed by precipitation-dependent (periglacial) rivers flowing from the south, but just as well by streams flowing from the north that were fed by the meltwater from the ice sheet (Weckwerth 2013; Weckwerth and Chabowski 2013; Pisarska-Jamroży 2015; Pisarska-Jamroży et al. 2015). The position and extent of the basin was determined by valleys and glacial basins which evolved before the Last Glacial Maximum (LGM), i.e. before 24-19 ka ago (Makowska 1980; Wysota et al. 2009; Weckwerth 2010, 2013; Marks 2012).

The oldest valleys known in the area became infilled by fluvial sands and gravels which accumulated during the Holstenian interglacial (western part of Toruń Basin; Brykczyński 1986; Uniejewska and Nosek 1992; Marks 2005). Palynology records and results of OSL dating (Noryśkiewicz 1978; Makowska 1980; Wysota 2002) indicate that a next generation of river valleys evolved during the Eemian interglacial (Figs. 2, 3) when rivers bypassed parts of the Mesozoic basement in the area that had become uplifted by glacio-isostasy (Weckwerth 2013). 
Fig. 1 Location of the study area, showing the extent of the Scandinavian ice sheet during the Weichselian glaciation
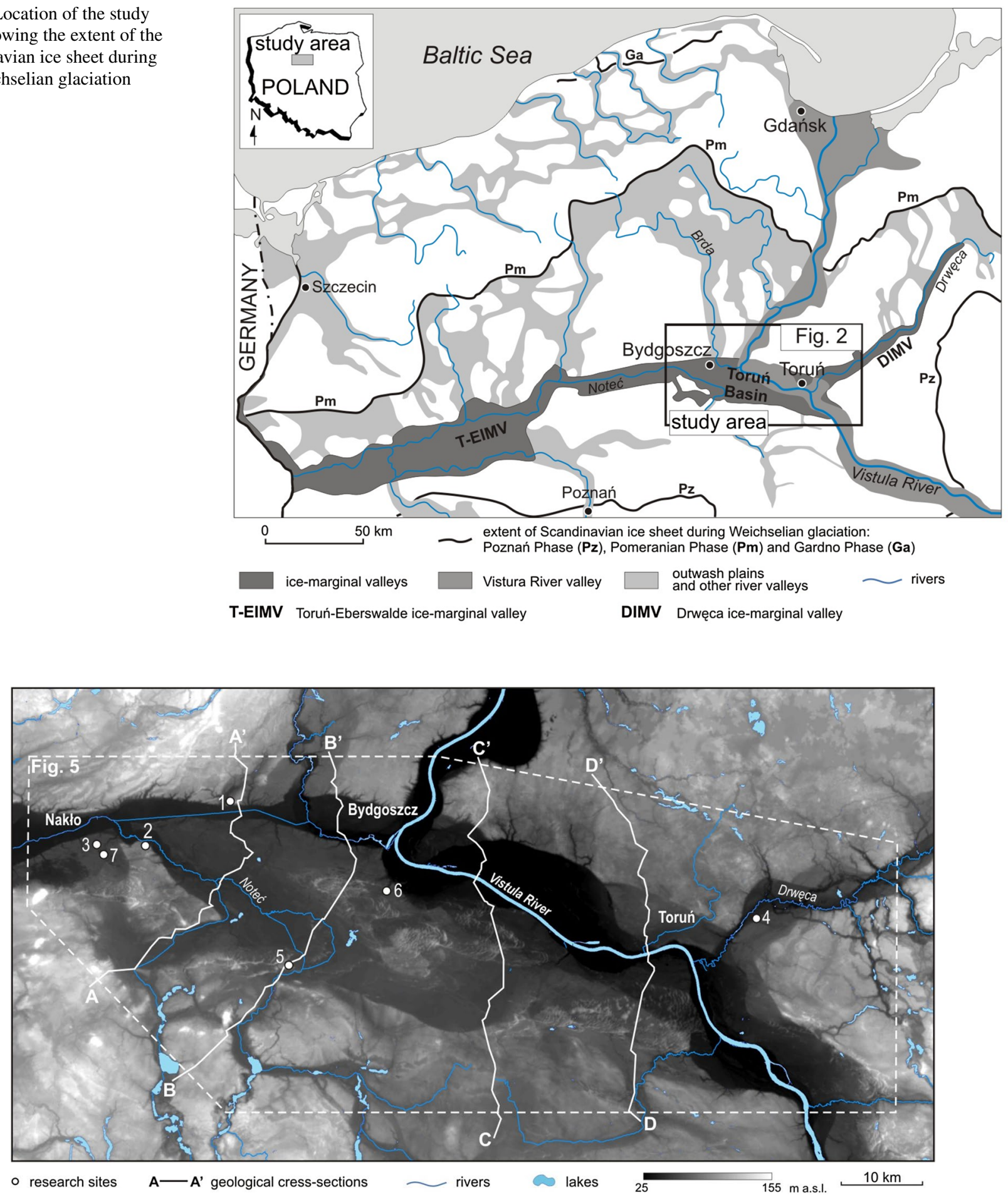

Fig. 2 Relief of the Torun Basin and the location of research sites and geological cross-sections (research sites: 1-Zielonczyn, 2-Chobielin, 3-Rozwarzyn, 4-Młyniec, 5-Nowe Dąbie, 6-Wypaleniska, 7-Paterek)

This glacio-isostatic rebound induced river incision at the end of Saalian glaciation (Termination II; postglacial transgression and sea-level stabilization; Marks 2005; Siddall et al. 2006) and was also a major cause of the development of Last-Interglacial valleys in areas of Mesozoic basement subsidence.

Weichselian fluvial and glaciofluvial successions are the fills of these Termination-II created valleys. They 

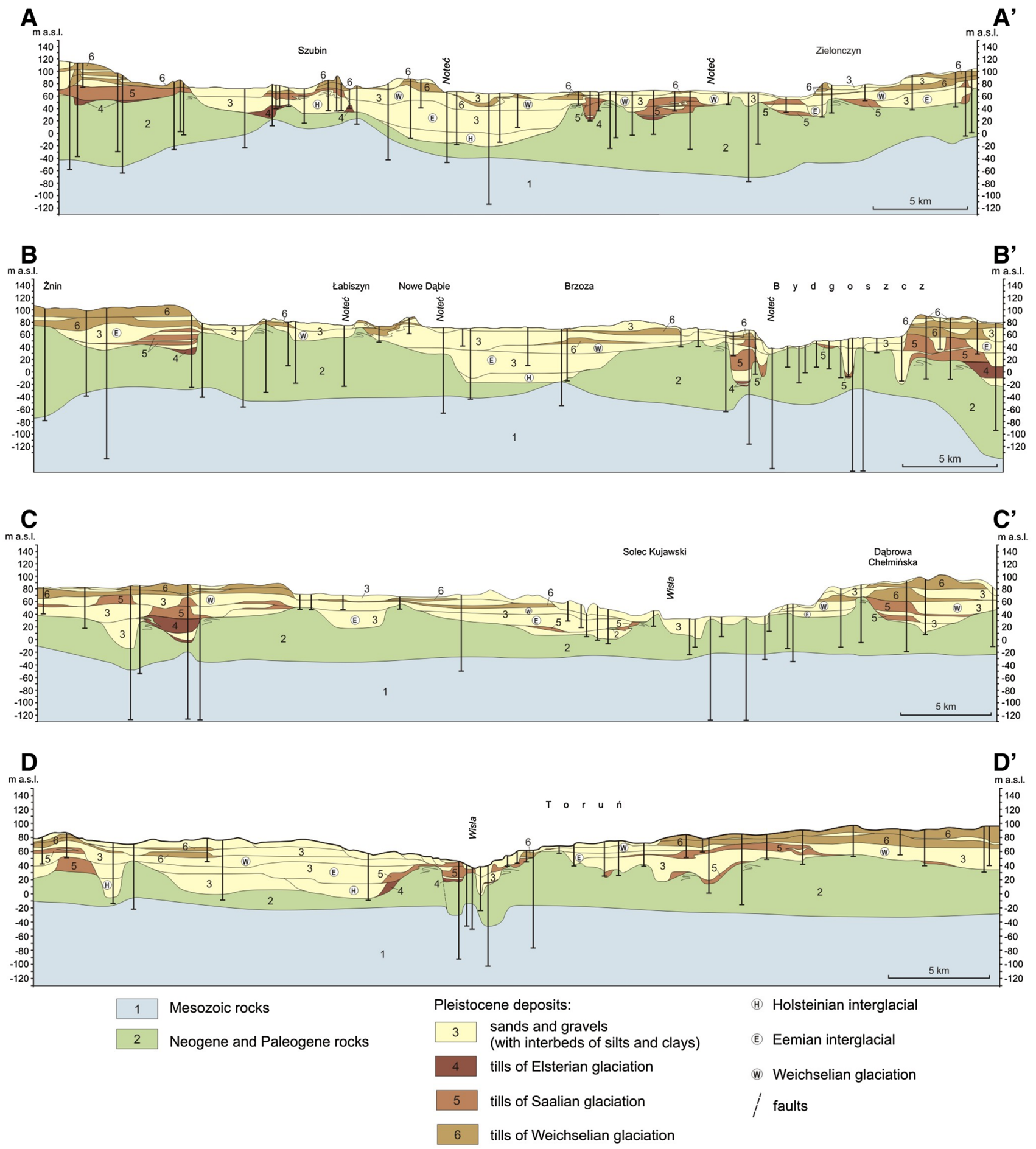

Fig. 3 Geological cross-sections in the western part of the Toruń Basin (after Weckwerth 2010, 2013, modified)

constitute three fluvial formations separated by tills or by glaciolacustrine sediments (Fig. 4). The first fluvial formation is the Rzeczkowo Formation, which is over 29 ka years old (Wysota 2002; Wysota et al. 2009; Weckwerth et al. 2011). The two younger fluvial formations are the Zielonczyn Formation (deposited between 28 and 21 ka years ago) and the Noteć Formation, which includes deposits of the Torun-Eberswalde ice-marginal valley (pradolina) that dates from 17 to 16 ka years ago on the base of geomorphological records and $14 \mathrm{C}$ dating (Galon 1961; Tomczak 1987; Wiśniewski 1990; Weckwerth et al. 2011; Weckwerth 2013). The lower members 


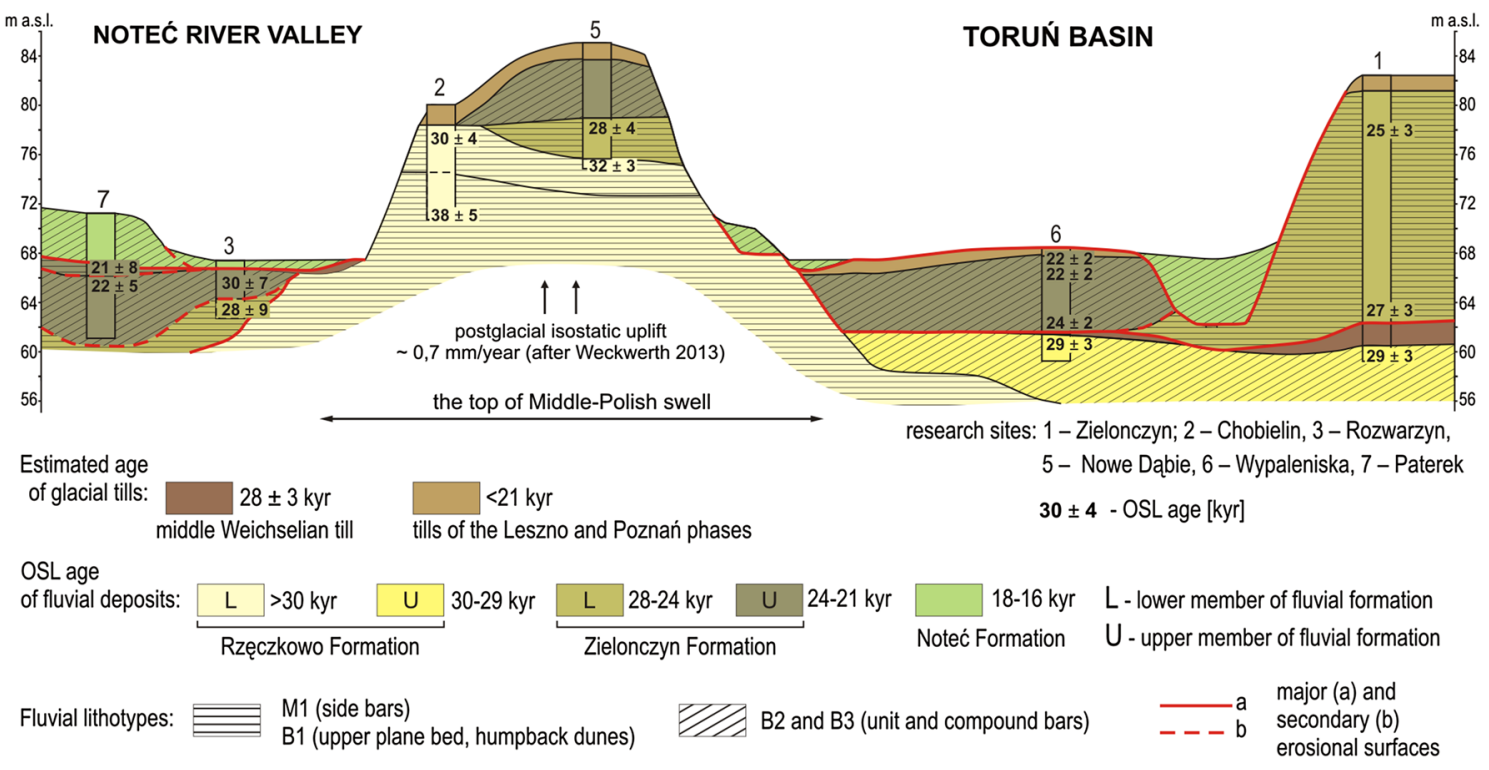

Fig. 4 Synthetic lithological and stratigraphical cross-section of the Toruń Basin and Noteć River valley (after Weckwerth 2013, modified)

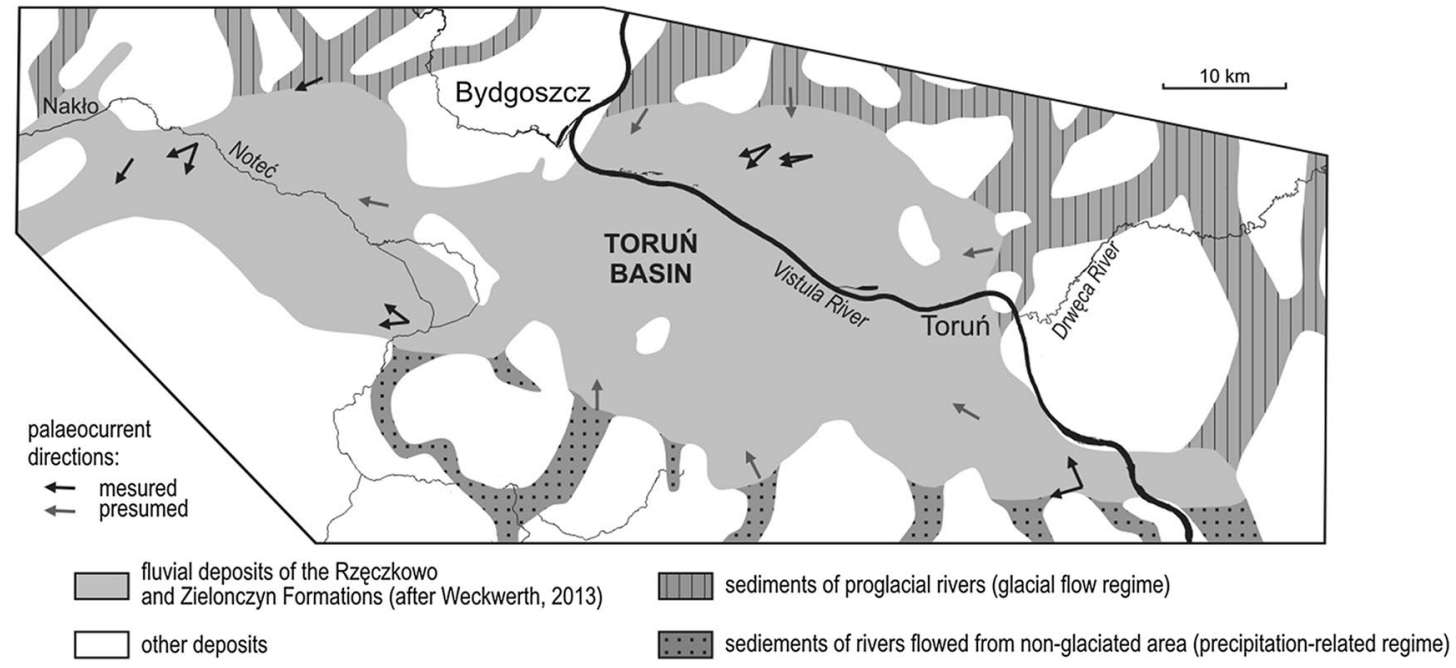

Fig. 5 Toruń Basin and its fluvial system during the deposition of the Rzęczkowo and Zielonczyn Formations (after Weckwerth and Chabowski 2013, modified)

of the Rzęczkowo Fm. and Zielonczyn Fm. were accumulated in precipitation-fed rivers (Figs. 4, 5), whereas the sediments of their upper members were deposited by meltwaters (Wysota et al. 1996; Wysota 2002; Molewski 2007; Weckwerth 2013; Weckwerth et al. 2013). All members of the Rzęczkowo and Zielonczyn Formations were deposited in the Torun Basin which was widened and deepened by glacial erosion and deformation during the Late Pleistocene (Weckwerth 2013). This large depression represents a sedimentary basin which merges narrow valleys running from the south and tracks of meltwater streams flowing from the north (Fig. 5). This basin was drained to the west of Bydgoszcz through the antecedent river gaps which developed near Nakło due to glacio-isostatic rebound that induced river incision at the end of Saalian and Weichselian glaciations (Figs. 2, 5) (Weckwerth 2013). 
Table 1 Symbols of lithofacies and codes for channel bedforms and macroforms (after Miall 1978, 2006; Eyles et al. 1983; Zieliński 1995, 1998; Zieliński and Pisarska-Jamroży 2012; modified by the present author)

\begin{tabular}{|c|c|c|}
\hline \multicolumn{2}{|l|}{ Lithofacies code } & \multirow[t]{2}{*}{ Lithogenetic code } \\
\hline Textural symbols & Structural symbols & \\
\hline D-diamicton & $\mathrm{m}$-massive & GL—glacial deposition \\
\hline $\mathrm{G}$-gravels & $\mathrm{h}$-horizontal stratification, lamination & GB—gravelly bedforms and bars \\
\hline $\mathrm{S}$-sands & 1-low-angle cross-stratification (small and medium scale) & SP-scour-pool infill, scouring channel \\
\hline \multirow[t]{7}{*}{$\mathrm{F}$ - silt and/or clay } & i-low-angle inclined stratification (large scale) & $\mathrm{CC}$ - chute channel \\
\hline & $\mathrm{t}$ - trough cross-stratification & UP-upper plane bed \\
\hline & p-planar cross-stratification (small and medium scale) & SB—sandy bedforms \\
\hline & $\mathrm{f}$-large scale planar cross-stratification & FM-u-transverse bars \\
\hline & $\mathrm{r}$-ripple cross-lamination & FM-c-transverse bars \\
\hline & w-wavy lamination & LM—side bars, point bars \\
\hline & $\mathrm{e}-$ scour infill & $\begin{array}{l}\mathrm{OF} \text { - overbank forms: crevasse splays } \\
\text { and sand sheets }\end{array}$ \\
\hline
\end{tabular}

\section{Methods}

\section{Lithofacies analysis of fluvial sediments}

Field data from seven key sites show that the fluvial deposits occur below the Weichselian tills and till-remnants. The conditions at which fluvial deposition took place were reconstructed on the basis of the structural and textural features. This made it possible to restrict the genetic origins of the various lithofacies to bedforms of specific channel types. In the studied exposures, several lithofacies coexist and form lithofacies associations related to specific fluvial sub-environments (Table 1). In turn, these lithofacies associations form groups of macroscale strata sets (cf. Bridge 1993), that we have related to the depositional sedimentary environments.

\section{Grain-size distribution}

The grain-size distribution of the sands and gravels was determined by sieving at 1- $\varphi$ intervals, whereas the silt and mud fractions were measured with a laser particle-size analyser (Analysette 22) at 0.25- $\varphi$ intervals. The sediments were classified texturally according to the scale proposed by Udden and modified by Wentworth (1922). The statistical parameters of the grain-size distribution (median grain diameter, mean grain-size and sorting, skewness and kurtosis of the grain-size distribution) were assessed on the basis of the formulas by Folk and Ward (1957).

\section{Age control}

Fluvial successions that compose lithostratigraphic unit, identified by lithological characteristics and stratigraphic position, distinct from other beds, were classified as formation which can be divided into members characterized by specific lithology (Tucker 2003; Marks et al. 2014). The ages of fluvial formation were obtained by OSL dating method, applying the single aliquots regenerative (SAR) dose protocol (Murray and Wintle 2000; Wintle and Murray 2006). The ages dataset was described and discussed in author's earlier studies under the terms of ages overestimation and reliability in paleogeographical context (Weckwerth et al. 2011, 2013; Weckwerth 2013).

\section{Paleohydraulic analysis}

A series of paleo-flow parameters were quantified in the following manner. The river gradient $(S)$ for the fluvial successions of the Rzęczkowo and Zielonczyn Formations was calculated using the Du Boy equation $\tau=\rho g D S$ and the Schields equation $\theta=\tau / \rho g R d_{50}$ (Paola et al. 1992; Julien and Wargadalam 1995; Dade and Friend 1998; Dade 2000; Paola 2000; Frings 2008; Weckwerth 2011), where $\tau$ is the bed shear stress $\left(\mathrm{kgm}^{-1} \mathrm{~s}^{-2}\right), \rho$ is the water density $\left(\mathrm{kgm}^{-3}\right), D$ is the hydraulic radius (mean flow depth for braided rivers) (m), $\theta$ is the dimensionless Shields parameter, $g$ is the gravitational acceleration $\left(=9.81 \mathrm{~ms}^{-2}\right), R$ is the relative excess density of the sediment particles, and $d_{50}$ is the median grain diameter (m) (Fig. 6).

The flow depth $D(\mathrm{~m})$ is related to the height of the bedforms and macroforms in a river channel (Simons and Richardson 1962), and thus proportional to the thickness of the individual lithofacies of planar and trough cross-stratified sands (Simons and Richardson 1962; Allen 1982; Weckwerth 2011; Zieliński 2014) (Fig. 6). The fluvial erosion effects were taken into account during the estimation of flow depth $(D)$ because in braided rivers the mean preserved set thickness for bedforms is about 0.7-0.8 (cf. Paola and Borgman 1991; Mohrig et al. 2000). For massive or horizontally 


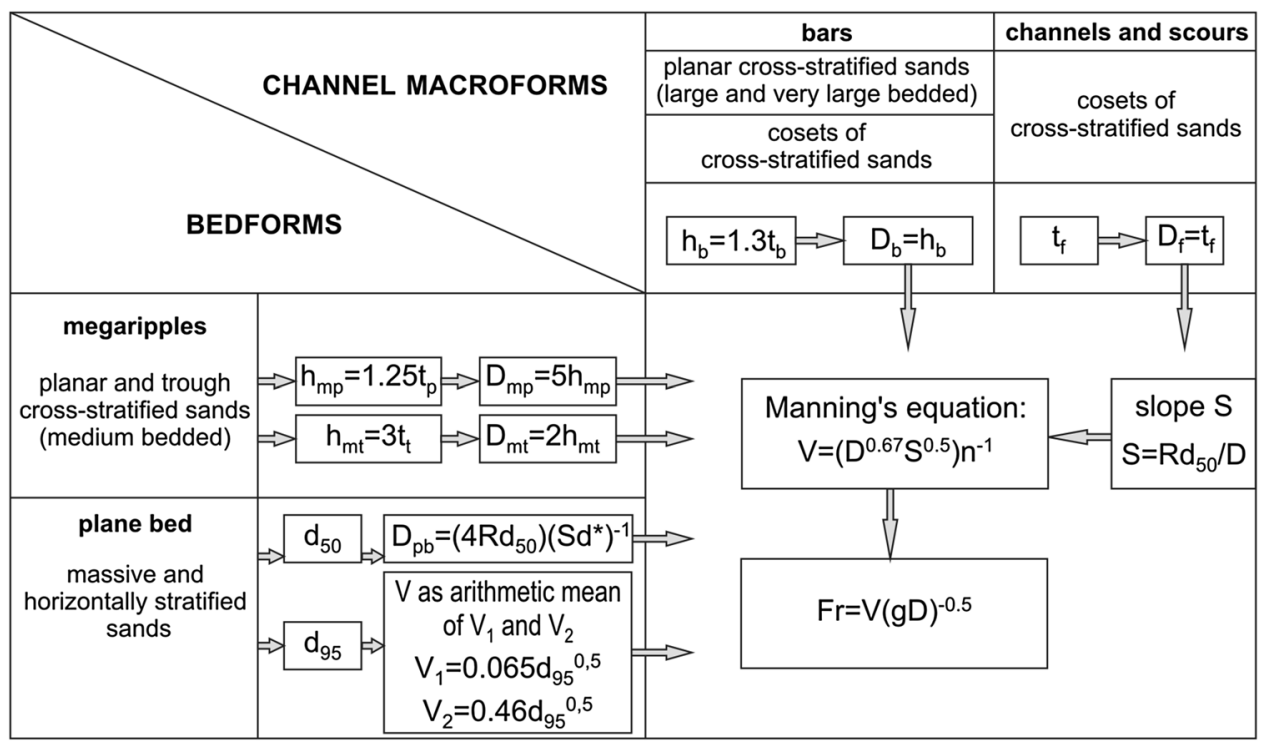

Fig. 6 Scheme of paleohydraulic calculation principles for buried sedimentary facies of sand-bed-braided rivers. $t_{\mathrm{p}}$ - thickness of lithofacies of planar-stratified sands (medium bedded), $h_{\mathrm{mp}}$-megaripple height calculated on the basis of the thickness of lithofacies of planarstratified sands, $t_{\mathrm{t}}$-thickness of lithofacies of trough-stratified sands (medium bedded), $h_{\mathrm{mt}}$-megaripples height calculated on the basis of the thickness of lithofacies of trough-stratified sands, $D_{\mathrm{mp}}$-mean flow depth calculated on the basis of the thickness of lithofacies of planar-stratified sands, $D_{\mathrm{mt}}$-mean flow depth calculated on the basis of the thickness of lithofacies of trough-stratified sands, $t_{\mathrm{b}}$ - thickness of planar cross-stratified sands (large and very large bedded) or cosets of cross-stratified sands, $h_{\mathrm{b}}$-transverse bar height, $D_{\mathrm{b}}$-mean

stratified sediments, the estimation of the flow depth was based on the median grain diameter $\left(d_{50}\right)$ (Williams 1983; Julien and Raslan 1998). The results are consistent with the method that determines the flow depth on the basis of the lithofacies thickness (Leclair and Bridge 2001; Bridge 2003).

The average current velocity was estimated with Manning's equation, $V=\left(D^{2 / 3} S^{1 / 2}\right) n^{-1}$, where $\mathrm{n}$ is Manning's coefficient (see Julien 2002). The Froude number was determined to compare with the sedimentological inferences and to establish an independent estimation of flow regime. This non-dimensional parameter was calculated using the equation $F r=V(g D)^{-0.5}$ (Dey 2014) which shows the ratio of inertia forces to the gravity forces (Fig. 6). The sinuosity of the river channel was estimated using the equation $\mathrm{SN}=1-(\mathrm{VR} / 252)^{-2}$, where $\mathrm{SN}$ is the channel sinuosity and $\mathrm{VR}$ is the maximum angular range of the mean azimuth of the crossbeds (Langbein and Leopold 1966; Miall 1976). flow depth calculated on the basis of transverse bar height, $t_{\mathrm{f}}$-thickness of channel and scour infill, $D_{\mathrm{f}}$-mean flow depth calculated on the basis of thickness of channel and scour infill, $d_{95}-95$ th percentile of grain-size distribution, $D_{\mathrm{pb}}$-mean flow depth calculated for plane bed (after Julien and Raslan 1998), $d^{*}$-dimensionless particle diameter (after Julien and Raslan 1998) [other symbols are explained in the text; $h_{\mathrm{mp}}$ was calculated after Saunderson and Jopling (1980) and Zieliński (2014), $h_{\mathrm{mt}}$ and $D_{\mathrm{mt}}$ after Leclair and Bridge (2001), $D_{\mathrm{mp}}$ after Zieliński (2014), $h_{\mathrm{b}}$ after Paola and Borgman (1991), $D_{\mathrm{b}}$ after Mohrig et al. (2000), $V_{1}$ and $V_{2}$ after Williams (1983), $S$ after Paola et al. (1992), Dade and Friend (1998), Dade (2000), Paola (2000) and Frings (2008)]

\section{Sedimentological characteristics of the fluvial deposits}

\section{Sediments of the lower members of the Weichselian fluvial formations}

\section{Fluvial succession at the Chobilelin site}

Sediments which represent the lower member of the Rzęczkowo Fm. are present at the Chobielin site and were deposited between $38.3 \pm 4.7$ and $29.5 \pm 3.9 \mathrm{ka}$ ago (Figs. 4, 7). These are $9 \mathrm{~m}$ thick and consist of three similar lithofacies associations- $\mathrm{Si}(\mathrm{SFw}), \mathrm{Si}(\mathrm{Sm}, \mathrm{Sr})$ and $\mathrm{Si}(\mathrm{Sm}, \mathrm{Sr}, \mathrm{Src}, \mathrm{Se})$ - in which a large-scale and low-angle inclined stratification of fine-grained sands $(\mathrm{Si})$ dominate (Fig. 7). The laminae of lithofacies $\mathrm{Si}$ dip up to $8^{\circ}$ to the south and the south-east. Sands and silts with wavy lamination $(\mathrm{SFw})$ and ripple cross-lamination $(\mathrm{Sr})$ and beds with climbing ripples: (lithofacies Src), scour infillings (Se) and massive sands (Sm) are also present in this fluvial succession. All the mentioned lithofacies form fining-upward sequences $\mathrm{Sm} \rightarrow \mathrm{Si} \rightarrow \mathrm{Sr}(\mathrm{Src}) / \mathrm{Se}$. 
ZIELONCZYN

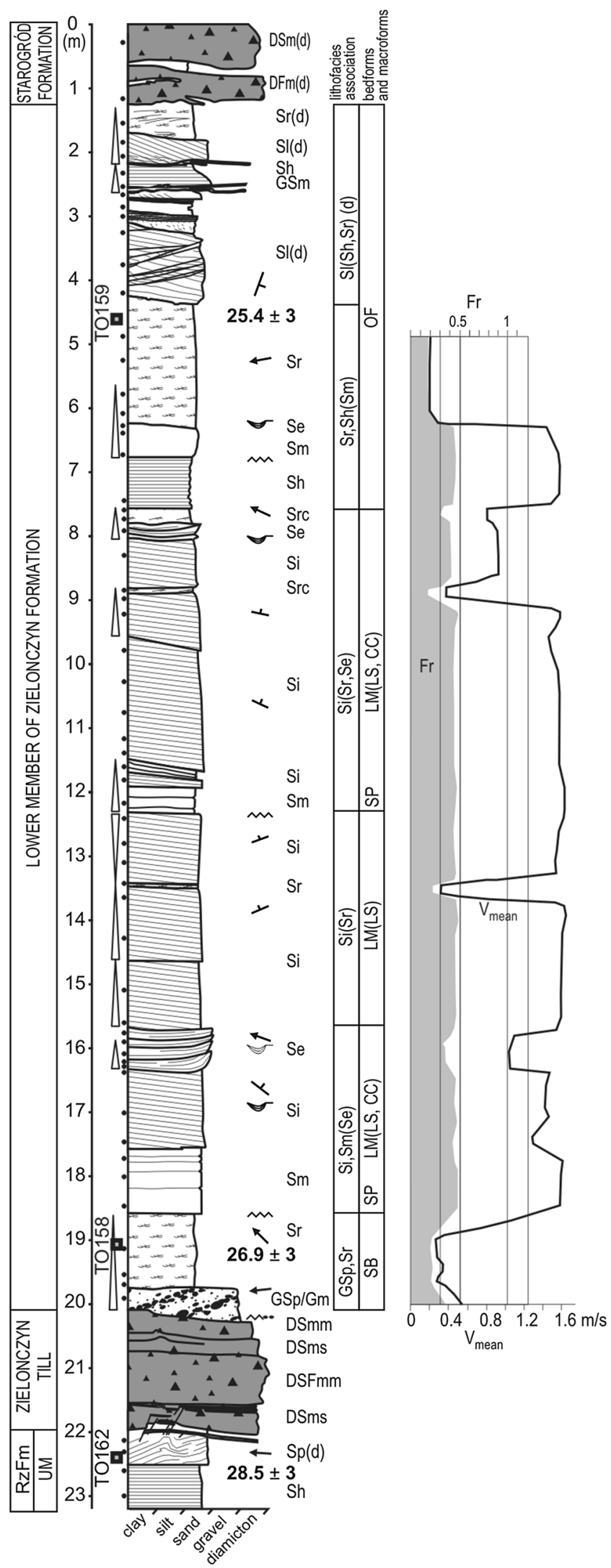

\section{CHOBIELIN}

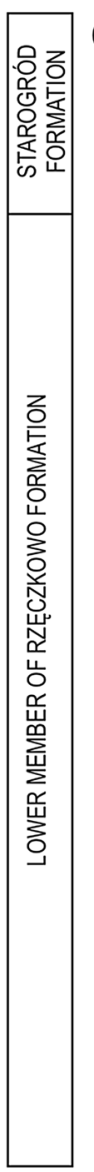

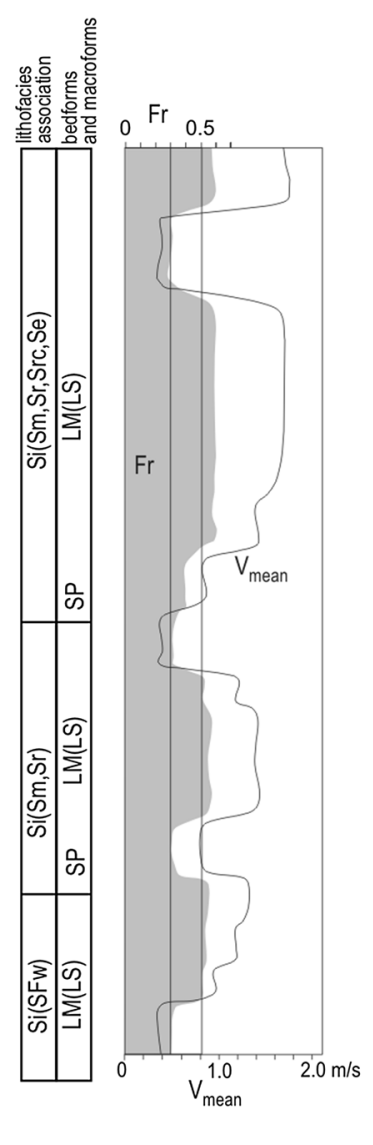

Key to symbols:

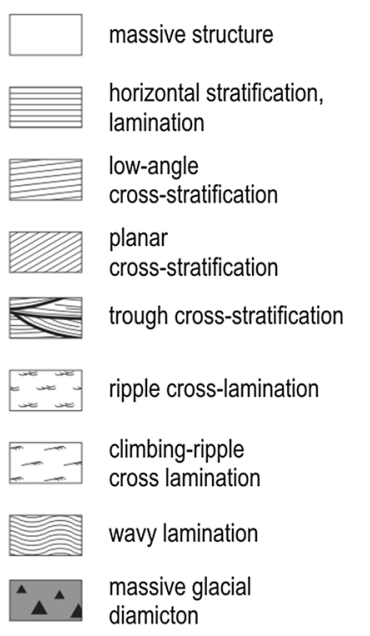

RzFm - Rzeczkowo Formation UM - upper member of fluvial formation

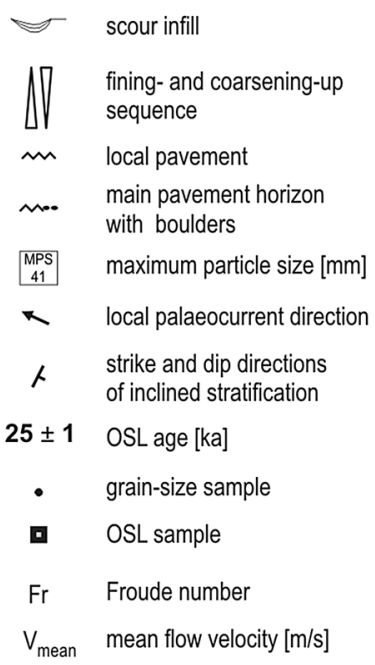

(d) deformations

Fig. 7 Lithofacies log of the Zielonczyn and Chobielin sites (explanation of lithofacial and lithogenetic codes in Table 1) 

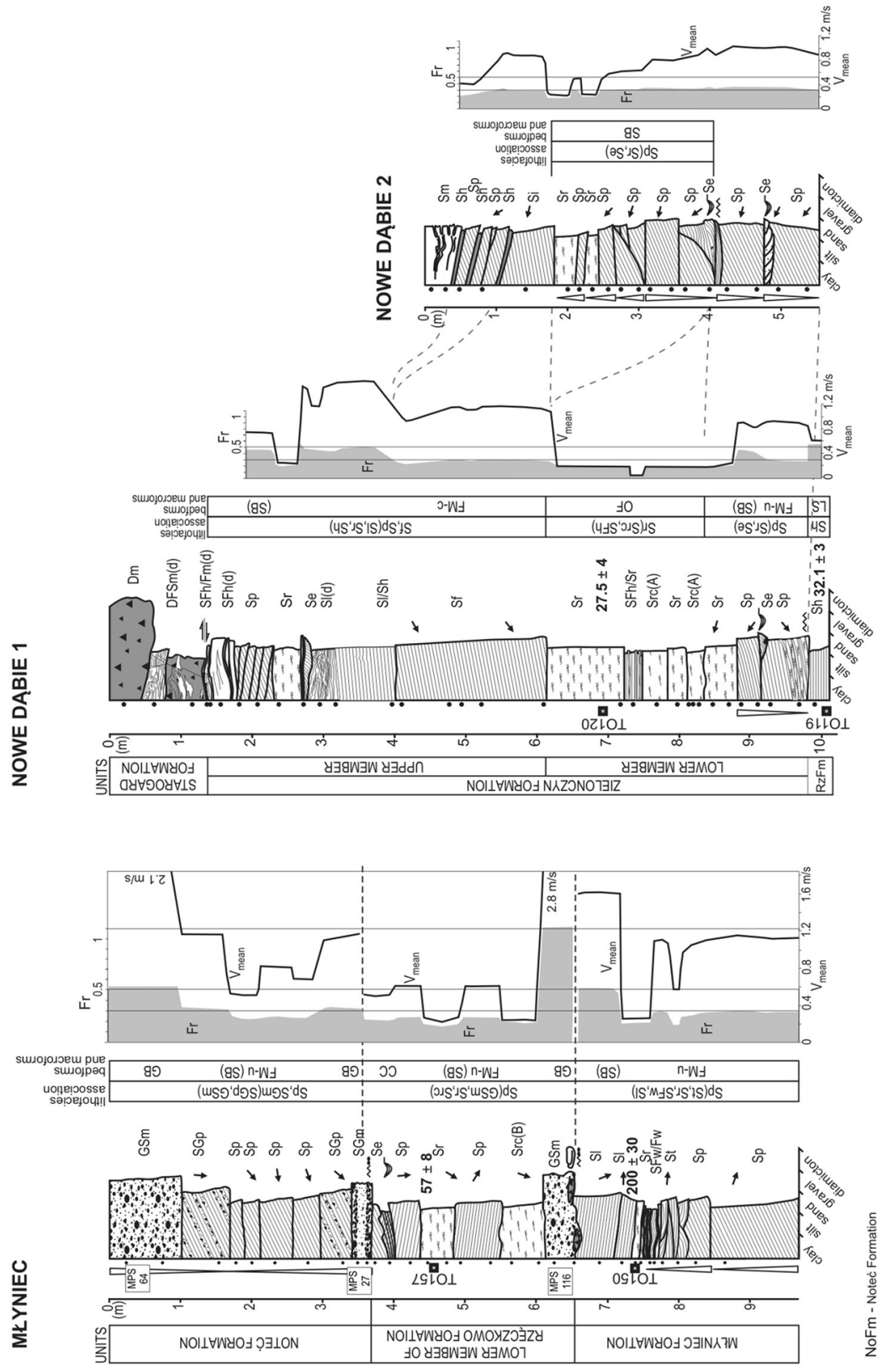

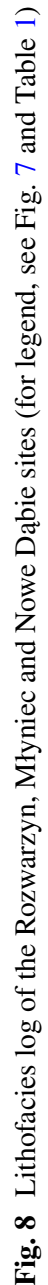


The fluvial succession at Chobielin can be divided into two parts on the basis of the grain-size distribution. The lower part occurs at the depth of 9-5.6 m and consists of well-sorted fine-grained sands, in which the average value of median grain diameter $\left(d_{50}\right)$ is $0.14 \mathrm{~mm}$. The upper part, between 5.6 and $1.7 \mathrm{~m}$, is built of moderately sorted finegrained sands in which the median grain diameter $\left(d_{50}\right)$ is about $0.19 \mathrm{~mm}$.

\section{Fluvial succession at the Zielonczyn site}

Sediments of the lower member of Zielonczyn Fm. are exposed at the Zielonczyn site and reach a thickness of $19.5 \mathrm{~m}$. These were deposited between $26.9 \pm 3$ and $25.4 \pm 3 \mathrm{ka}$ ago (Figs. 4, 7) and consist of six lithofacies associations (Fig. 7). The basal part of the first lithofacial association (GSp,Sr) is built of cross-stratified and poorly sorted sandy gravels (lithofacies GSp) in which the average median grain diameter $\left(d_{50}\right)$ is $1.77 \mathrm{~mm}$. These sediments are overlain by ripple cross-laminated and well-sorted finegrained sands (lithofacies $\mathrm{Sr}$ ) in which the average median grain diameter $\left(d_{50}\right)$ is $0.15 \mathrm{~mm}$. The grain-size distributions of lithofacies association GSp,Sr are symmetric and mesoor platykurtic. The next lithofacies associations $[\mathrm{Si}, \mathrm{Sm}(\mathrm{Se})$, $\mathrm{Si}(\mathrm{Sr})$ and $\mathrm{Si}(\mathrm{Sr}, \mathrm{Se})]$ form three similar sequences $\mathrm{Sm} \rightarrow \mathrm{Si} \rightarrow \mathrm{Sr} / \mathrm{Se}$. Their lower segments are composed of massive fine-grained sands $(\mathrm{Sm})$, in which median grain diameters $\left(d_{50}\right)$ vary between 0.15 and $0.16 \mathrm{~mm}$. Middle segments consist of sets of large scale and low-angle inclined stratification of fine-grained sands $(\mathrm{Si})$ in which laminae $\operatorname{dip}$ at $6^{\circ}-14^{\circ}$ to the northeast, southeast and southwest (Fig. 7). Sediments of lithofacies Si are normally graded (the median grain diameters decrease from 0.17 to $0.15 \mathrm{~mm}$ ) and well or moderately sorted. The uppermost segments of each sequences comprise rippled fine-grained sands $(\mathrm{Sr})$ in which the median grain diameters differ between 0.13 and $0.16 \mathrm{~mm}$. These segments may contain sandy scour infillings of a depth up to $0.4 \mathrm{~m}$ (lithofacies Se, median grain diameter $d_{50}$ between 0.16 and $0.18 \mathrm{~mm}$ ).

The upper part of the fluvial succession at the Zielonczyn site is composed of two lithofacies associations $\mathrm{Sr}, \mathrm{Sh}(\mathrm{Sm})$ and $\mathrm{Sl}(\mathrm{Sh}, \mathrm{Sr})(\mathrm{d})$ (Fig. 7). The first is dominated by ripple cross-laminated fine-grained sands $(\mathrm{Sr})$ the thickness of which is $2 \mathrm{~m}$. These sediments lie on the horizontally stratified sands (Sh) or on massive sands (Sm). The second lithofacies association $[\mathrm{Sl}(\mathrm{Sh}, \mathrm{Sr})(\mathrm{d})]$ comprises lithofacies of medium-scale and low-angle cross-stratified fine-grained sands (Sl), which are interbedded with ripple cross-laminated sands (Sr) and with horizontally stratified sands (Sh). Their sedimentary structures were deformed by the development of reverse faults and clastic dykes.
Fluvial deposits at the Rozwarzyn, Mtyniec and Nowe Dabie sites

Fluvial deposits of the lower members of Weichselian fluvial formations were also found at the Rozwarzyn, Młyniec and Nowe Dąbie sites (Fig. 8). These sediments are $5 \mathrm{~m}$ thick and contain three lithofacies associations at the Rozwarzyn site. The first of them [lithofacies association $\mathrm{Sh}, \mathrm{Sl}(\mathrm{Sr}, \mathrm{Sp})]$ is dominated by middle- and small-scale beds of horizontally stratified and low-angle cross-stratified sands (median grain diameters $d_{50}$ are in the range of $0.15-0.16 \mathrm{~mm}$ ). These sediments are well sorted and have symmetric or positively skewed grain-size distributions. Locally, they are interbedded with ripple cross-laminated sands and with small- and middle-scale lithofacies of planar cross-stratified sands ( $\mathrm{Sp}$ ) which are coarser (average $d_{50}=0.22 \mathrm{~mm}$ ) and moderately sorted. Additionally, normally graded, large-scale and lowangle cross-stratified sands ( $\mathrm{Sl}$ ) occur in the upper part of the lithofacies association $\mathrm{Sh}, \mathrm{Sl}(\mathrm{Sr}, \mathrm{Sp})$. This lithofacies is characterized by sigmoidal crossbeds and varied thicknesses (from 0.7 up to $2.5 \mathrm{~m}$ ).

The lower members of the Weichselian fluvial successions are represented by lithologically similar deposits at the Młyniec and Nowe Dąbie sites (Fig. 8). Sands showing medium-scale and small-scale planar cross-stratification (Sp) and rippled fine-grained sands were encountered in both sites; scour infillings additionally occur (lithofacies Se). These deposits are moderately well and moderately well sorted, while their median grain diameter $\left(d_{50}\right)$ varies from 0.15 up to $0.29 \mathrm{~mm}$. Moreover, massive and matrixsupported sandy gravels (lithofacies GSm) were recognized at the Młyniec site, whereas the lithofacies association $\mathrm{Sr}$ (Src,SFh) was observed at Nowe Dąbie site. Sandy beds of the ripple-drift cross-lamination occur commonly in this lithofacies association. Additionally, horizontally laminated silty sands (lithofacies SFh) were identified at a depth of 7.2-7.6 m (Fig. 8).

\section{Sediments of the upper members of the Weichselian fluvial formations}

The upper member of the Zielonczyn Formation at the Nowe Dąbie site contains two lithofacies associations $\mathrm{Sp}(\mathrm{Sr}, \mathrm{Se})$ and $\mathrm{Sf}, \mathrm{Sp}(\mathrm{Sl}, \mathrm{Sr}, \mathrm{Sh})$ (Fig. 8). The first of them is $2.2 \mathrm{~m}$ thick and comprises medium-scale planar cross-stratified sands (lithofacies Sp, profile Nowe Dąbie 2; Fig. 8). These reverse graded sediments (median-grain diameter $d_{50}$ increases from 0.29 up to $0.34 \mathrm{~mm}$ ) are moderately well and well sorted and interbedded with scours infillings (lithofacies Se) or with ripple cross-laminated fine-grained sands ( $\mathrm{Sr}$ ). Lithofacies association $\mathrm{Sf}, \mathrm{Sp}(\mathrm{Sl}, \mathrm{Sr}, \mathrm{Sh})$ has a thickness of $4.75 \mathrm{~m}$. Its lower part is dominated by fine- and medium-grained sands of inclined stratification (lithofacies Sf, median-grain 

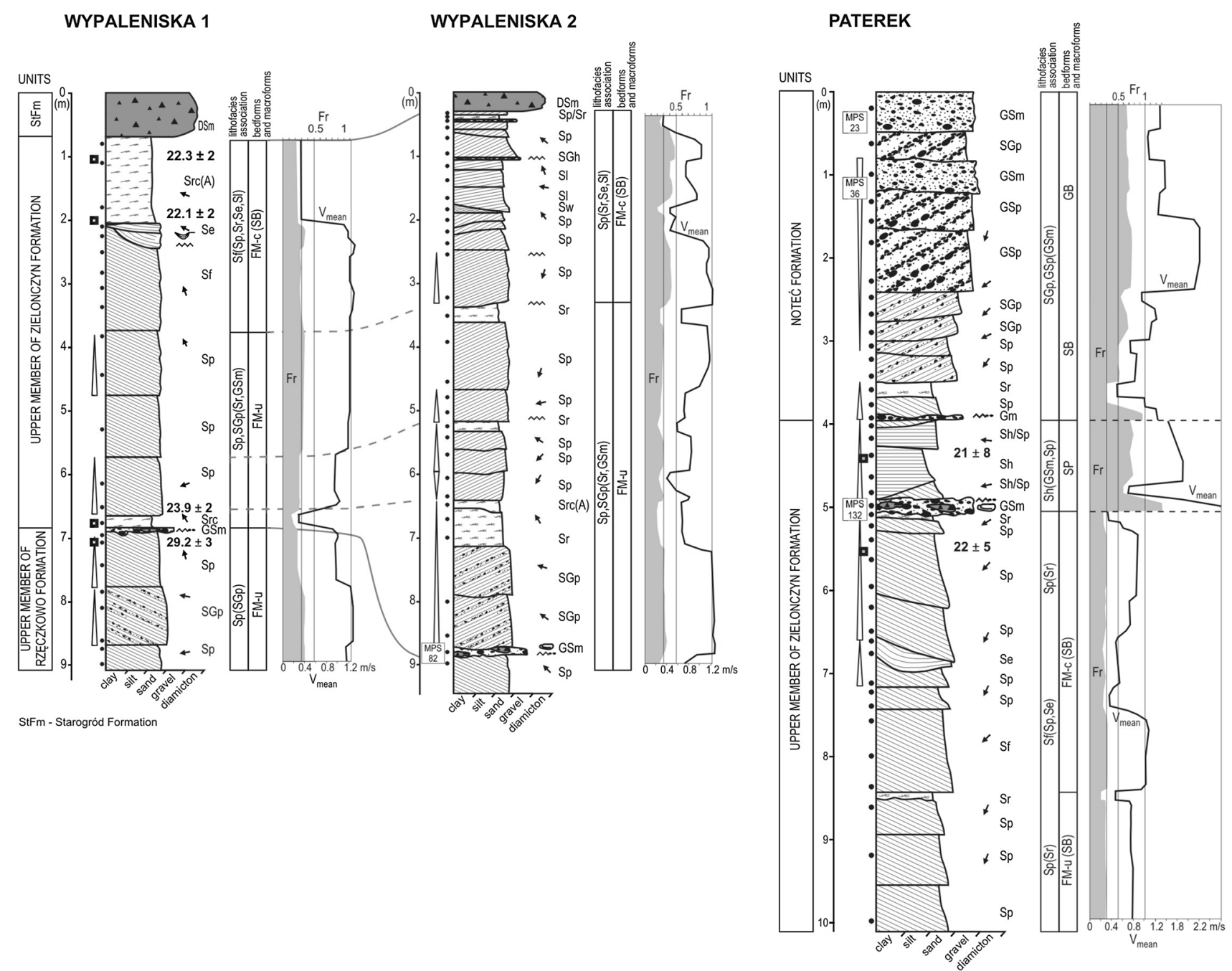

Fig. 9 Lithofacies log of the Wypaleniska and Paterek sites (for legend, see Fig. 7 and Table 1)

diameter $d_{50}$ from 0.16 up to $0.31 \mathrm{~mm}$ ) which reach a thickness up to $2.1 \mathrm{~m}$ and are well and moderately sorted (profile Nowe Dąbie 1; Fig. 8). These sediments are overlain by lowangle cross-stratified sands (Sl), sands of scours infills (Se) and by small-scale planar cross-stratified sands (Sp) with interbeds of horizontally stratified sands (Sh). Similar largescale sandy beds of planar and inclined stratification (lithofacies $\mathrm{Sp}$ and Sf, respectively) were recognized in the upper part of the fluvial succession at the Rozwarzyn site (Fig. 8).

Fluvial sediments at the Wypaleniska site represent two Weichselian fluvial formations which were deposited up to $29 \pm 3 \mathrm{ka}$ ago (Rzęczkowo Fm.) and between 24 and 22 ka ago (Zielonczyn Fm.; Weckwerth et al. 2011; Weckwerth 2013). The first of them (Rzęczkowo Fm.) consists of medium- and fine-grained planar cross-stratified sands with an admixture of granules and pebbles [lithofacies association $\mathrm{Sp}$ (SGp), Fig. 9]. These deposits are normally graded (median-grain diameter $d_{50}$ decreases from 0.40 to $0.17 \mathrm{~mm}$ ) and moderately well and well sorted, while their grain-size distributions are negatively skewed and leptokurtic.

Sediments of the Zielonczyn Fm. are represented by two lithofacies associations $\mathrm{Sp}, \mathrm{SGp}(\mathrm{Sr}, \mathrm{GSm})$ and $\mathrm{Sf}(\mathrm{Sr}, \mathrm{Se}, \mathrm{Sl})$ at the Wypaleniska site (Fig. 9). The first lithofacies association comprises cosets of medium-scale lithofacies of planar cross-stratified fine- and medium-grained sands (mediangrain diameter $d_{50}$ changes from 0.17 to $0.39 \mathrm{~mm}$, profile Wypaleniska 1) or two-part sequences $\mathrm{Sp} \rightarrow \mathrm{Sr}$ which consist of planar cross-stratified sands ( $\mathrm{Sp}$ ) with cappings of rippled and fine-grained sands (Sr) (profile Wypaleniska 2). Sands of planar cross-cosets are moderately well and moderately well sorted, whereas their grain-size distributions vary from negatively to very positively skewed. The second lithofacies association $[\mathrm{Sf}(\mathrm{Sp}, \mathrm{Sr}, \mathrm{Se}, \mathrm{Sl})]$ is dominated by very thickly planar cross-bedded fine-grained sands (median-grain diameters vary between 0.21 and $0.32 \mathrm{~mm}$; Fig. 9). These sediments are overlain by medium- and small-scale planar 
Fig. 10 Typical Weichselian fluvial lithofacies associations and fluvial styles in relation to the flow regime conditions (changes of Froude number) and sediments size ( $d_{50}$ variations) reflecting river channel pattern transformations (explanation of lithofacial and lithogenetic codes in Table 1)

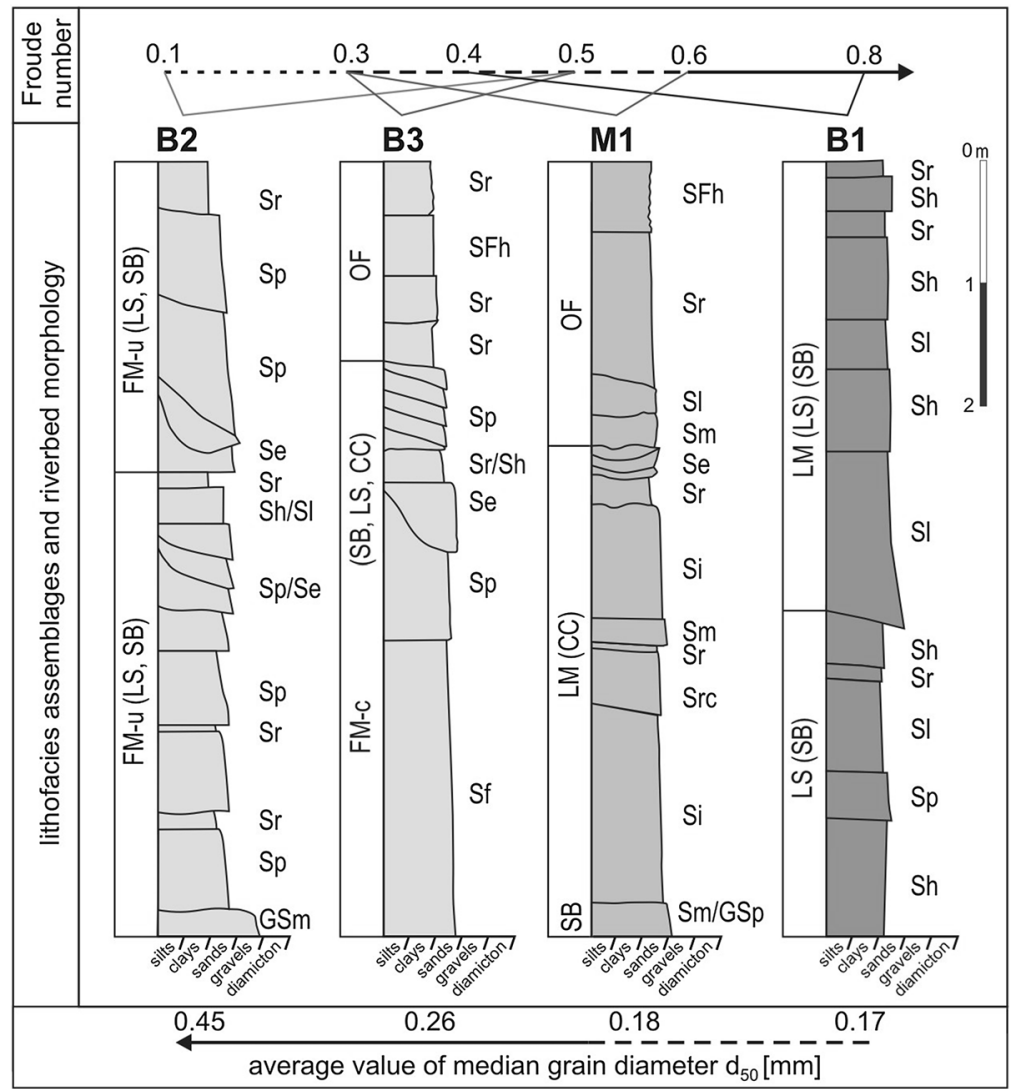

cross-stratified sands (Sp), sandy scour infillings (Se), rippled sands ( $\mathrm{Sr}$ ) and low-angle cross-stratified sands ( $\mathrm{Sl}$ ).

A similar fluvial succession was recognized at the Paterek site, where the sandy cosets of mid- and large scale planar cross-stratification (lithofacies Sp and Sf, respectively),

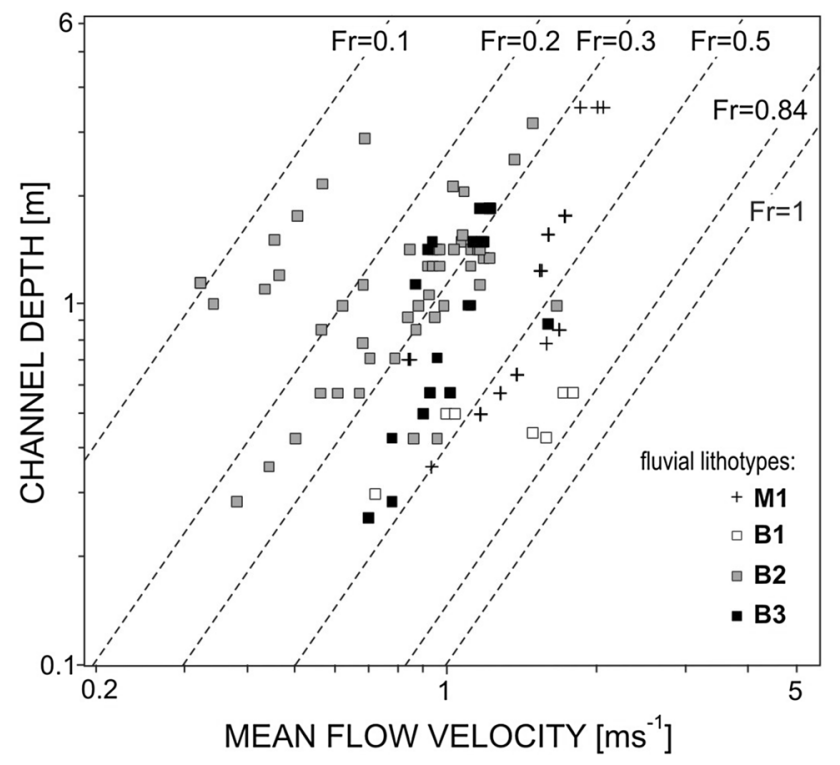

Fig. 11 Channel depth in relation to water flow velocity and flow regime (Froude number) for Weichselian fluvial lithotypes rippled sands ( $\mathrm{Sr}$ ) and sandy scour infillings (Se) form twopart sequences $\mathrm{Sp} \rightarrow \mathrm{Sr}$ and $\mathrm{Sf} \rightarrow \mathrm{Se} / \mathrm{Sp}$. Their lower segments (lithofacies $\mathrm{Sp}$ and $\mathrm{Sf}$ ) comprise medium-grained and moderately well-sorted sands (median-grain diameters $d_{50}$ are in the range $0.40-0.54 \mathrm{~mm}$ ) which are characterized by positively and very positively skewed grain-size distribution. The upper segments consist of small- and mediumscale lithofacies $\mathrm{Sp}, \mathrm{Se}$ and $\mathrm{Sr}$ in which fine-grained sands predominate (median-grain diameters $d_{50}$ vary from 0.15 up to $0.40 \mathrm{~mm}$ ).

The upper member of Zielonczyn Fm. at the Paterek site is built of lithofacies association $\mathrm{Sh}(\mathrm{GSm}, \mathrm{Sp})$. It's basal part contains massive pebbles with a sandy matrix (lithofacies GSm, average median-grain-diameter $d_{50}=8.15 \mathrm{~mm}$ ) (Fig. 9). These sediments are overlain by horizontally stratified fine-grained sands (Sh) which are normally graded (median-grain-diameter $d_{50}$ decreases from 0.24 to $0.17 \mathrm{~mm}$ ) and moderately sorted. These are interbedded with small-scale planar cross-stratified and mediumgrained sands (lithofacies $\mathrm{Sp}$, average median grain diameter $d_{50}=0.41 \mathrm{~mm}$ ). 


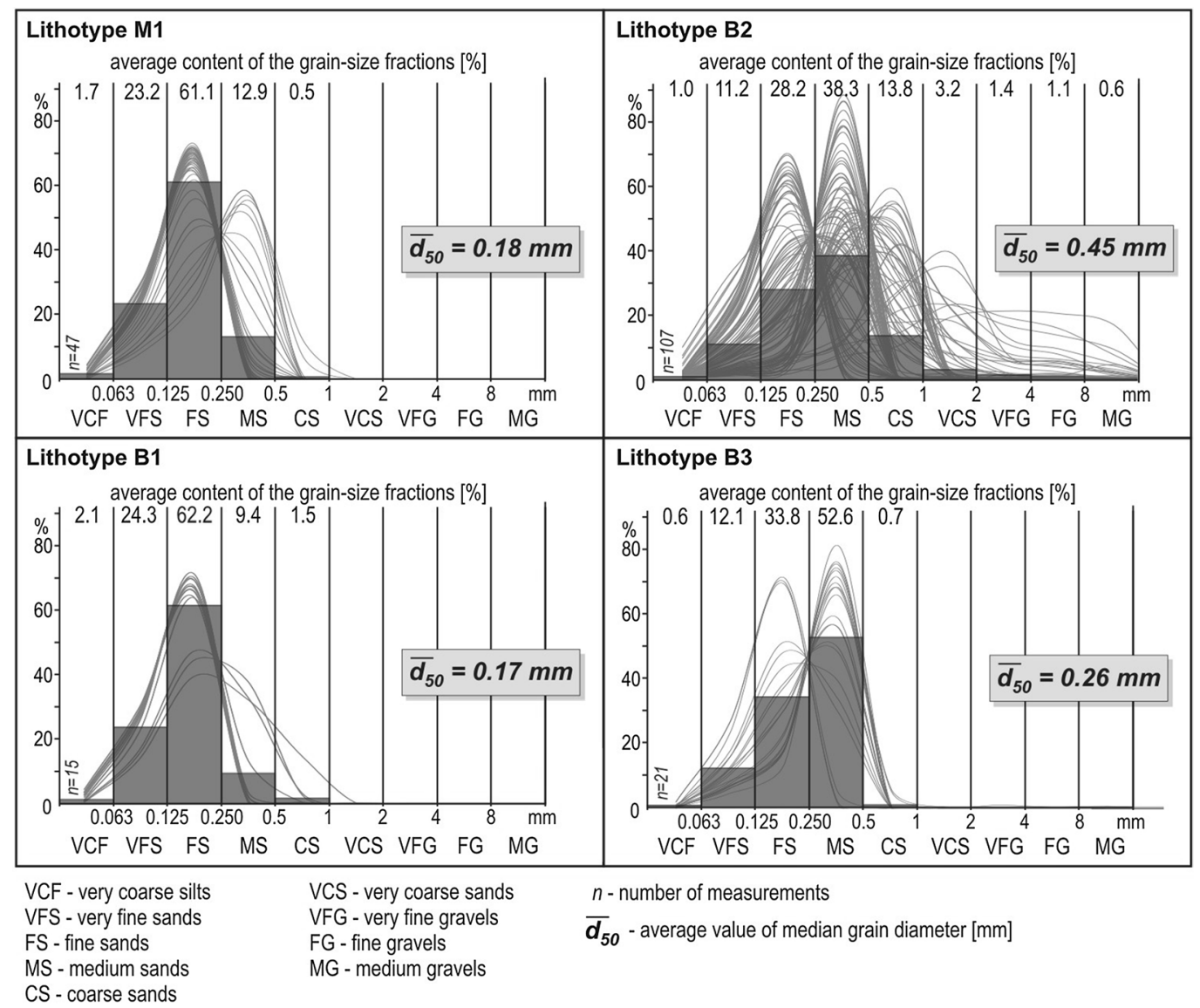

Fig. 12 Grain-size compositions of Weichselian fluvial lithotypes in the Torun Basin

\section{Fluvial lithotypes, riverbed morphology and channel patterns}

The sedimentological results of Weichselian fluvial successions in the Torun Basin allowed for four fluvial lithotypes to be recognized: one of a meandering-style sand-bed river type (M1), and three of braided-style sand-bed river styles (B1, B2 and B3). These lithotypes relate to the sand-bed rivers of different fluvial style.

\section{Lithotype of a sand-bed, high-energy meandering river (M1)}

The lithotype M1 is represented by lithofacies association $\mathrm{Si}(\mathrm{Sm}, \mathrm{Sr}, \mathrm{Se})$ (Chobielin and Zielonczyn sites; Figs. 7, 10) which are arranged into stacked sequences $\mathrm{Sm} \rightarrow \mathrm{Si} \rightarrow \mathrm{Sr}(\mathrm{Se})$. The indicative large-scale lithofacies of low-angle inclined stratification of fine-grained sands ( $\mathrm{Si}$ ) capped by rippled sands (Sr) and sandy scours infillings (Se), represent pointbar sequences (Tunbridge 1981, 1984; Stear 1983; Miall 1985, 2006; Olsen 1988, 1989; Julien 2002; Bridge 2003). The surfaces of point-bars sloped at up to $8^{\circ}$ in the case of a shallow channels (depth up to $1 \mathrm{~m}$ ) and at $8^{\circ}-14^{\circ}$ if channels reached a depth of $1-3.5 \mathrm{~m}$. These low inclined point-bar surfaces developed in channels of 20-30 m wide, the sinuosity of which varied from 1.25 up to 1.5 (see Leeder 1973).

The deposition of fluvial lithotype M1 took place mostly under transitional water flow conditions from subcritical to supercritical or under supercritical flow. These conditions were related especially to the high water flow velocity (up to $1.7 \mathrm{~ms}^{-1}$ ), whereas the Froude number reached a maximum only of 0.6 (Fig. 7,11). Similar low values of the Froude number (0.16-0.68) for supercritical flow were observed in modern sand-bed braided and meandering rivers (Leopold et al. 1964; Karim 1995; Julien and Raslan 1998; Prent and Hickin 2001). Moreover, the experimental results (Cheel 1990b; Julien and Raslan 1998; Best 2005; Fourrière et al. 2010) reveal that the supercritical flow may occur in a wide Froude number range 0.21-1.6. These true low values of the Froude number, experimentally obtained for a sequence of which the sedimentology indicates conditions of supercritical flow, may reflect the high rate of fine-grained sands suspended in a water column (Bridge and Best 1988; Baas and Best 2002; Best 2005). Moreover, 
the average median grain diameter $\left(d_{50}\right)$ of fluvial lithotype M1 is $0.18 \mathrm{~mm}$ (Fig. 12). Low-angle cross-stratification and parallel lamination (inclined or horizontal) commonly occur in these fine-grained sands, as was reported usually in sands characterized by median grain diameter in the range $0.1-0.3 \mathrm{~mm}$ and transported under the condition of the Froude number lower than 0.84 (Ashley 1990; Southard and Boguchwal 1990; Southard 1991).

The high transport rate of fine-grained sands of the fluvial lithotype M1 caused suppression of turbulence in the moving bedload dispersion (see Allen and Leeder 1980). Thus, the stable upper-plane bed and inclined parallel stratification of point-bar sequences (lithofacies $\mathrm{Si}$ ) were formed due to the migration of low-relief bed waves of up to $20-25 \mathrm{~mm}$ high and $1.3 \mathrm{~m}$ long (see Bridge and Best 1988; Paola et al. 1989; Best and Bridge 1992). Similar supercritical water flow conditions were responsible for the deposition of massive sands (lithofacies Sm; Chobielin site; Figs. 7, 10) (see Alexander et al. 2001; Duller et al. 2008) as a result of scour-pool infilling (Gorrell and Shaw 1991; Russell et al. 2007) in a river thalweg. Moreover, two-dimensional dunes migrated and sandy-gravelly upper flow regime sheets developed in this riverbed section (lithofacies GSp and SGm, respectively; Zielonczyn site; Fig. 7) (Fielding 2006). The rippled sands (Sr) and sandy chute cut-off infillings (Se) which form the upper segments of point-bar sequences, are indicators of waning flow conditions at the end of flood events and reflect episodes of sedimentation and erosion (Farrell 1987; Zieliński 1992, 1993; Miall 2006).

The depositional environment of the fluvial lithotype M1 and its high-energy nature show similarities to the sedimentary environment of flashy, ephemeral, sheet flood, sandbed braided river (Biju Creek type; see McKee et al. 1967; Tunbridge 1981, 1984; Miall 1985, 2006). However, the common occurrence of the low-angle inclined stratification of fine-grained sands (large scale lithofacies $\mathrm{Si}$ ) indicates lateral accretion of point-bars developed in an ephemeral stream (Stear 1983). Thus, the fluvial lithotype M1 recognized in the Torun Basin corresponds to the sedimentary environment of an ephemeral sandy meandering river (Miall 2006).

\section{Lithotype of a shallow, high-energy sand-bed braided river (B1)}

Sediments of the fluvial lithotype B1 are similar to the lithotype M1 in terms the textual features (Fig. 12). These deposits consist mainly of fine-grained sands (61-62\%), while the average value of the median grain diameter is $0.17-0.18 \mathrm{~mm}$. The key indicator of the lithotype B1 is the dominance of horizontally stratified fine-grained sands (lithofacies Sh) (Rozwarzyn site and the upper member of the Zielonczyn Fm. at the Paterek site; Figs. 9, 10). These lithofacies represent sheet-like beds veneering the floor of a sand-bed-braided river under the condition of supercritical flow (flow velocity up to $1.4 \mathrm{~ms}^{-1}$; Figs. 9, 11). The deposition within shallow streams was related to a wide sheet flow rather than channelised flow (flow depth 0.4-0.7 m) and took place at the low Froude number as a consequence of the high concentration of suspended sediments (Bridge and Best 1988; Cheel 1990a; Julien and Raslan 1998; Best 2005; Fourrière et al. 2010). Thus, the association of sediments in suspension with supercritical flow conditions implies abundant horizontally stratified sands (see Bridge and Best 1988; Paola et al. 1989; Southard 1991; Best and Bridge 1992; Alexander et al. 2001; Fourrière et al. 2010). These lithofacies were formed by the migration of antidunes and low-relief bed waves.

The upper segment of the lithotype B1 (large-scale and low angle crossbeds S1 with sigmoidal laminae) reflects lateral aggradation of humpback dunes (Kostaschuk and Villard 1996; Mohrig and Smith 1996; Kostaschuk 2000; Winsemann et al. 2011). The morphology of these bedforms was changeable due to a variable rate of suspended sediment concentration (Kostaschuk and Villard 1996; Mohrig and Smith 1996; Kostaschuk 2000; Lang and Winsemann 2013). Therefore, the deposition of fine-grained sands from the suspended load close to the bed controls the lee side of the slope angle (Kostaschuk et al. 2009). Additionally, the migration of humpback dunes that were formed around the transition to a supercritical flow could be considered as the initial phase of the riverbed transformation from upper-plane beds to the dunes of the lower flow regime (Fielding 2006).

Sedimentological features of the fluvial lithotype B1 are related to the Bijou Creek fluvial lithotype (McKee et al. 1967; Williams 1971; Tunbridge 1984) and to the model of the flashy, ephemeral, sheet flood, sand-bed river (distal, sheet flood braided model of Miall 1985). A similar fluvial succession was described by Wysota (2002) based on his studies of the Rzęczkowo Formation in the area of the Lower Vistula Valley (in the northern vicinity of the Torun Basin).

\section{Lithotype of a sand-bed braided river with unit bars (B2)}

The third fluvial lithotype B2 contains lithofacies association $\mathrm{Sp}(\mathrm{Sr}, \mathrm{Se}, \mathrm{Sl}, \mathrm{Sh})$ which is dominated by planar or trough cross-stratified sands (lithofacies $\mathrm{Sp}$ and $\mathrm{St}$, respectively; Figs. 9, 10). Typical lithofacies (Sp) are interpreted as related to the unit transverse bars and numerous sandy megaripples which covered the bed of a braided river (Smith 1978; Miall 1985; Bridge 1993, 2003). Sedimentation took place under the transitional conditions between the lower 
and upper parts of the lower flow regime (Froude number $\mathrm{Fr}$ $0.3-0.4$; Figs. 9, 10, 11). The surfaces of the unit bars were dissected by small cross-bar channels with sandy infillings (Se) and covered by sands of diminished dunes (Sl). During the waning flood stages, fine-grained sands were accumulated due to the tractional deposition under the condition of a ripple-phase bed (lithofacies $\mathrm{Sr}$ ).

The fluvial lithotype B2 was deposited from a low-energy flow characterized by a wide range of flow depth $(0.3-2.8 \mathrm{~m})$ and velocity of up to $1.6 \mathrm{~ms}^{-1}$ (Figs. 9, 11). Its maximum value occurred during the deposition of massive gravelly sandy sheet-like beds (GSm). The dominance of crossbeds (lithofacies $\mathrm{Sp}$ ) and minor sequences of laminated sand sheets, rippled sands and infillings of cross-bar channels are the common features of a "Plate-type" sand-bed braided river (shallow perennial braided; Miall 1985, 2006).

\section{Lithotype of a sand-bed-braided river with compound bars (B3)}

The lithotype B3 contains two lithofacies associations representing two fluvial sub-environments (Fig. 10). The main association $\mathrm{Sf}(\mathrm{Sp}, \mathrm{Sl}, \mathrm{Se}, \mathrm{Sr})$ was deposited within the channel of sand-bed-braided river and is dominated by large-scale planar cross-stratified sands (Sf) formed by the downstream migration of macroforms lee side (Nowe Dąbie, Wypaleniska and Paterek sites; Figs. 8, 9, 10) (Williams 1971; Cant and Walker 1978; Miall 1978, 1985; Miall and Jones 2003). This type of lithofacies predominantly occurred at the depths of 1.5-2.5 m below the surface of compound bars, which corresponds to those recognized in the South Saskatchewan River (Cant and Walker 1978; Sambrook Smith et al. 2006; Ashworth et al. 2011). These macroforms develop in a sandbed-braided river due to the unit transverse bar accretion and were also observed in the Platte (Blodgett and Stanley 1980; Allen 1983; Crowley 1983; Bridge 1993, 2003), Vistula (Babiński 1992), Yamuna (Best et al. 2003) and Niobrara (Skelly et al. 2003) rivers. Moreover, lithofacies Sf may well be interpreted as an effect of alternate bar migration (McCabe 1977; Crowley 1983), the crest of which was dissected by chute channels (lithofacies Se). Alternate bars may be subsequently subjected to transformation into midchannel compound bars (see Bridge 1985, 2003; Bridge et al. 1986; Babiński 1992).

The upper part of the compound bar succession was accumulated during the flood as a result of two-dimensional dunes and ripple migration (lithofacies $\mathrm{Sp}, \mathrm{Sr}$, respectively) which constituted sand shoals on the compound bar surface (Sambrook Smith et al. 2006; Ashworth et al. 2000, 2011). These bedforms may change rapidly into the diminished dunes (lithofacies Sl) or into upper plane beds (lithofacies Sh) due to the predominance of fine-grained sands transported within the stream under the condition of increasing water flow velocity caused by the decrease of the flow depth (see Ashley 1990; Southard 1991). Thus, variations of hydraulic parameters from the lower to upper flow regime tended to change the morphology of the compound bar surfaces in abundant areas of sand flats in sand-bed-braided river. Moreover, the compound bars were dissected by small cross-bar channels filled with sands (lithofacies Se) during the falling flood stage (Bridge and Lunt 2006).

The secondary lithofacies association $\mathrm{Sr}(\mathrm{Src}, \mathrm{SFh})$ of the fluvial lithotype B3 represents the overbank sub-environment where floodplain fines were accumulated as a result of overbank splay development and sheet flows (Fig. 10) (Bridge 2003; Bridge and Lunt 2006; Miall 2006).

Sediments of the fluvial lithotype B3 were deposited predominately under transitional conditions between the lower and upper parts of the lower flow regime $(F r \approx 0.3)$, although, there were transitional conditions from subcritical to supercritical flow in the zones of upper stage plane beds and in cross-bar channels (Figs. 10, 11). The water flow velocity was variable (up to $1.6 \mathrm{~ms}^{-1}$ ).

Qualitative features of the sedimentary environment of the fluvial lithotype B3 are similar to those in the South Saskatchewan River (Cant and Walker 1978) and are comparable with the depositional environment of deep perennial sand-bed braided river (Miall 1985, 1993, 1994, 2006) and with the lithotype D-3 described by Zieliński (1993) as sediments of aggrading-braided channels dominated by foreset bar accumulation.

\section{The relations between fluvial deposits and hydraulic conditions of the bedform development}

Hydraulic parameters of the rivers (e.g., water flow velocity) affect the development of bedforms, to which fluvial lithofacies correspond. Due to this the relationships between properties of fluvial sediments (structural and textural) and flow competence reflect hydrodynamic conditions of the fluvial depositional environment. For this reason, quantitative interpretation of sedimentary structures and textural properties of fluvial lithotypes is fundamental.

Lithotypes M1 and B1 are characterized by the most similar grain-size distributions (Fig. 12) which are generally symmetrical or-locally-show a negative skewness associated with an admixture of fractions coarser than average. Fine-grained sands represent $61-62 \%$ on average, while the average values of the median grain size distributions are 0.17 and $0.18 \mathrm{~mm}$ in the case of lithotypes M1 and B1, respectively. Although these lithotypes represent different riverbed patterns, their riverbed was in each stage modeled under supercritical flow regime or in transitional circumstances towards such flow conditions (Fig. 10). 
Fig. 13 Types of channel deposits in relation to the flow velocity, channel bedforms and Weichselian fluvial lithotypes

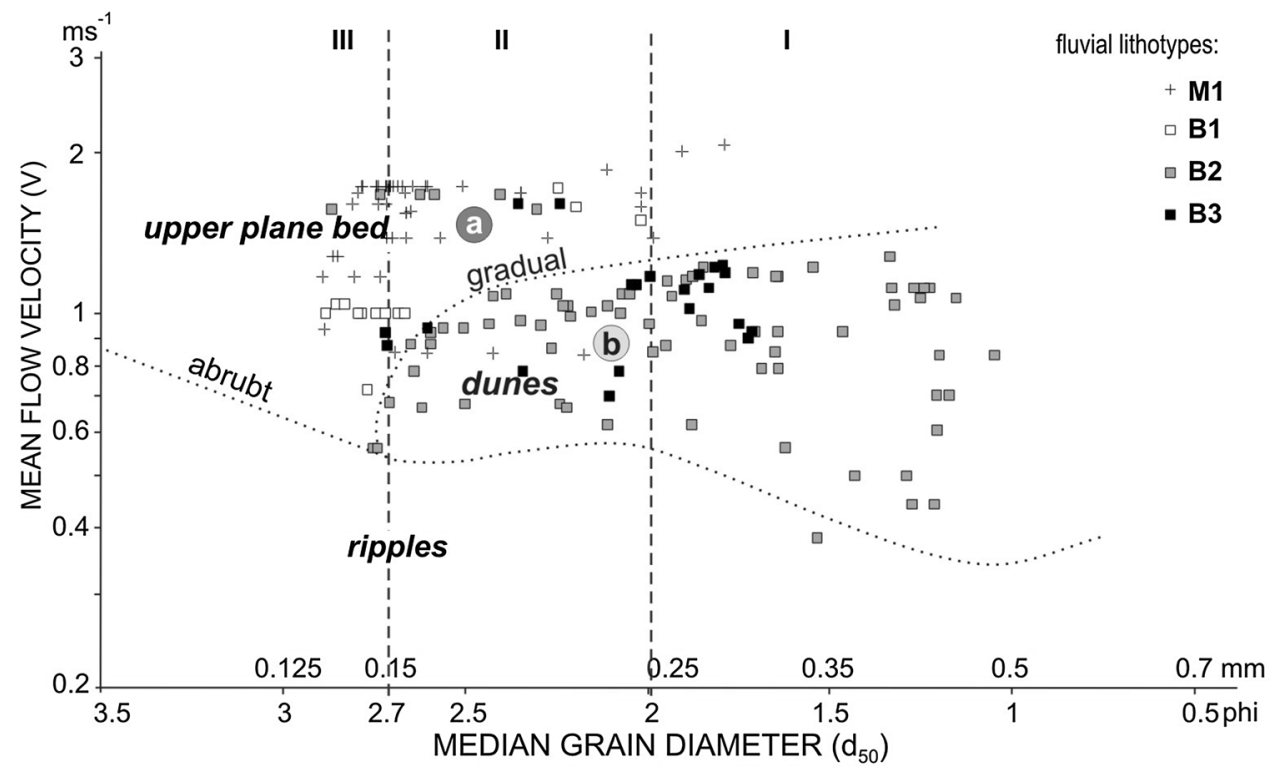

a meandering rivers and shallow braided rivers with upper plane bed (lithotypes M1 and B1)

b braided rivers with unit and compound bars (lithotypes B2 and B3)

I-III types of channel deposits

..... limits of bedforms occurrence (after Ashley, 1990)
Unit bars and dunes, characteristic of the lithotype B2, are composed mainly of sands with a different gravel admixtures (Fig. 12). As a result, these sediments vary from fine- and medium-grained sands (characterized by symmetrical grainsize distributions) to coarse- and very coarse-grained sands, or even gravels (very positive and very negative skewed) (Fig. 12). The average value of median grain diameters is $0.45 \mathrm{~mm}$.

The lithofacies of fluvial lithotype B3 comprise texturally homogeneous sands which contain of about $52 \%$ mediumgrained sands. The average value of median grain diameters of these deposits is $0.26 \mathrm{~mm}$ (Fig. 12). These deposits are better sorted than sands of the lithotype B2, show symmetrical grain-size distributions and in few cases slightly positive or negative skewness. Sediments of the lithotype B3 have a negligible contents of coarse-grained sands and gravels and for these reasons, the average median grain-size diameter is lower than for the lithotype B2 and is $0.26 \mathrm{~mm}$ (Fig. 12). These data indicate greater stability of hydrodynamic conditions of the depositional environment of the lithotype B3 in comparison with the lithotype B2.

An analysis of the relationship between texture characteristics of the Weichselian fluvial successions in relation to the conditions for the development of the river bedforms, allowed for the delimitation of the three types of fluvial deposits. The first type ("I" in Fig. 13) is represented by the sand-bed-braided river with bar-related sedimentation (" $b$ " in Fig. 13), transported mainly under condition of lower flow

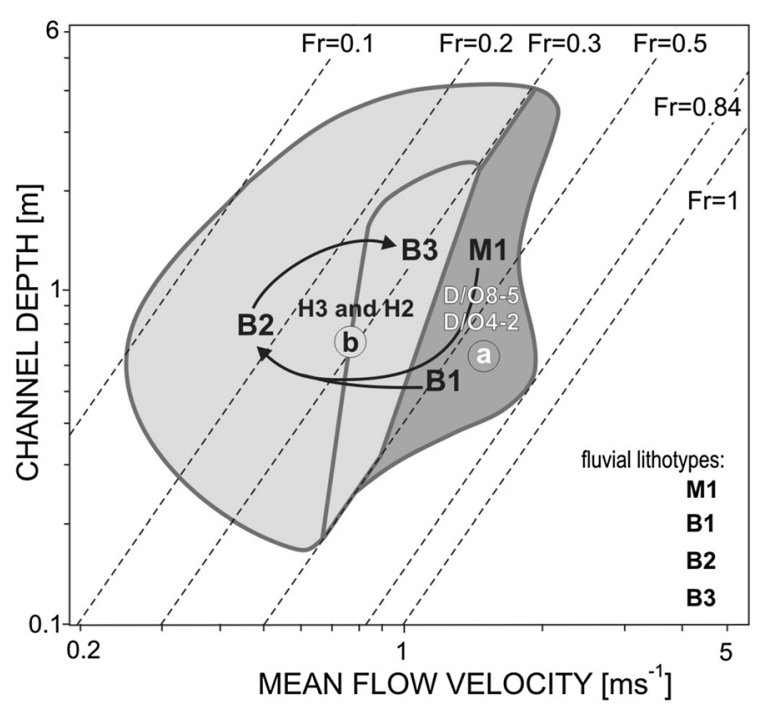

high-energy rivers

a (meandering and shallow braided rivers with upper plane bed, lithotypes M1 and B1)

b) less energetic rivers

(braided rivers with unit and compound bars, lithotypes B2 and B3)

flow boundary conditions

$\longleftarrow$ tends of the river channel pattern transformation

D/(0) Dansgaard-Oeschger cycles

H Heinrich cold events

Fig. 14 The model of river channel transformation during the Weichselian glaciation as an effect of climate oscillation 
regime (lithotypes B2 and B3). The sorting of these deposits becomes worse for sediments characterized by median grain diameter $\left(d_{50}\right)$ in the range of $0.25-0.5 \mathrm{~mm}$. The second type of the river channel deposits ("II" in Fig. 13) contains sands in which sorting is more poor with the decrease in median grain diameter from 0.25 to $0.15 \mathrm{~mm}$. Moreover, these sediments represent gradual changes from the lithotypes related to sand-bed-braided rivers with unit and compound bars (" $b$ " in Fig. 13) to the lithotypes of meandering rivers and shallow braided rivers with upper plane bed ("a" in Fig. 13), and hence changeable conditions from lower to the upper flow regime.

The third type of the channel sediments has an average grain-diameter $\left(d_{50}\right)$ lower than $0.15 \mathrm{~mm}$ ("III" in Fig. 13). These sands represent high-energy, sand-bed and shallowbraided rivers (lithotype B1) or ephemeral meandering rivers (lithotype M1). The sorting of these deposits gets worse with the increase in size of median grain diameter.

As is apparent from the relationship between the median grain diameter $\left(d_{50}\right)$ and the velocity of water flow $(V)$, the same fraction of the deposits may be transported in different hydraulic conditions (see Ashley 1990; Southard and Boguchwal 1990; Southard 1991). This applies mainly to the deposits of an average diameter $\left(d_{50}\right)$ smaller than $2.5 \mathrm{~mm}$ (types "II" and "III" in Fig. 13). Regardless of this, the median grain diameter of $0.15 \mathrm{~mm}$ may be the boundary between the channel sediments transported primarily in the conditions of the upper flow regime (type III of fluvial deposits) and deposits of sand-bed-braided rivers with transverse bars and dunes (types "I" and "II"; Fig. 13) (see Sly et al. 1983). Nevertheless, during the transportation of fine-grained sands ( $d_{50}$ lower than $0.15 \mathrm{~mm}$ ), there is a potential for ripples or an upper plane bed to develop (type III of channel deposits; Fig. 13), which refers flow competence to sediments transporting under conditions of different (lower or upper) flow regimes (see Ashley 1990; Southard and Boguchwal 1990; Southard 1991). For these reasons, the textual criterions $\left(d_{50}=0.25\right.$ and $\left.d_{50}=0.15 \mathrm{~mm}\right)$ cannot be unambiguous in hydrodynamic interpretation of fluvial deposits.

\section{Climate-derived transformation of riverbed morphology and flow conditions during Weichselian glaciation}

\section{Meandering and shallow-braided rivers}

Lithotypes of the high-energy rivers, forming the lower members of the Weichselian fluvial formations, were deposited as a result of the activities of precipitation-dependent rivers (Weckwerth and Chabowski 2013). Typical water flow conditions of meandering and shallow-braided rivers (area

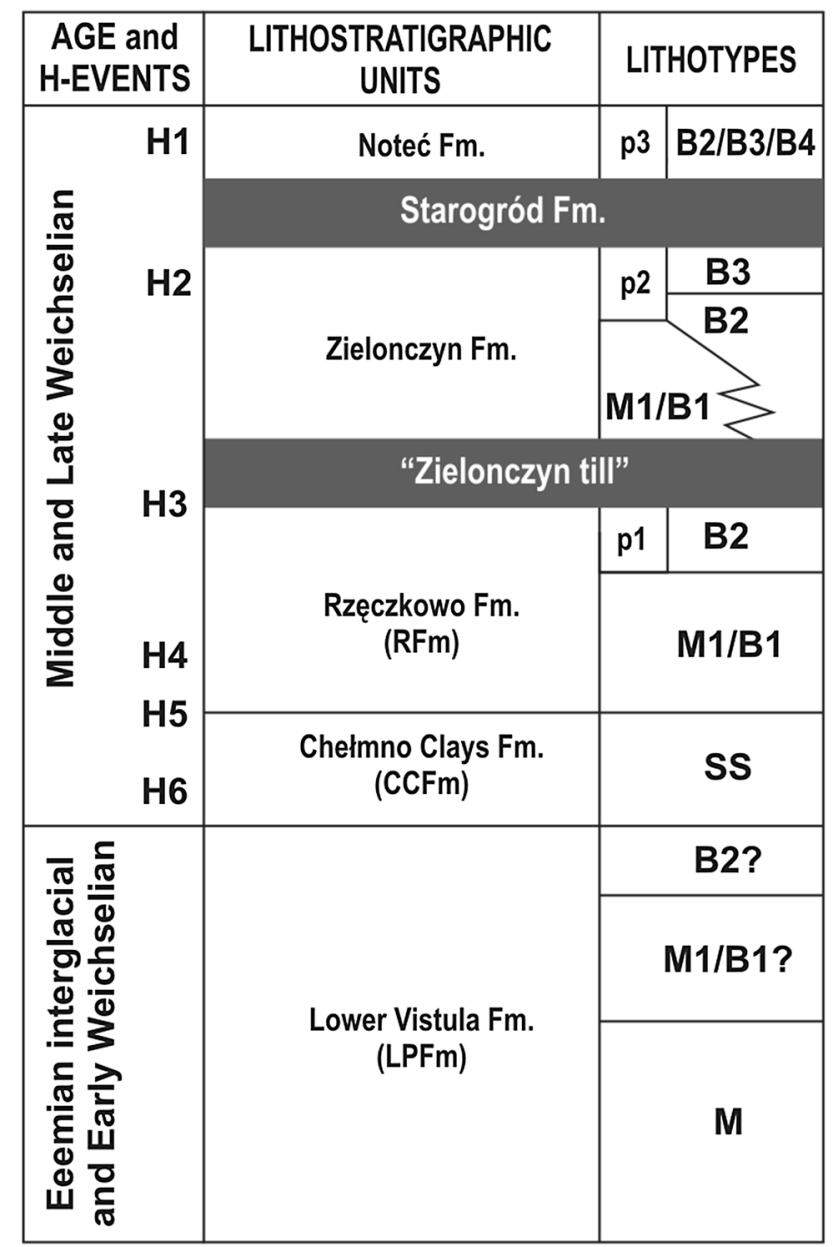

Fig. 15 The relation between lithostratigraphic units and Weichselian lithotype succession in the Torun Basin [M-litothotype of eemian meandering river after Makowska (1980); SS-lithotype of proglacial ice-dammed lake after Wysota (2002); M1, B1-B3-fluvial litothotypes deposited during Weichselian glaciation (analyzed in this study); B4-fluvial lithotype of high-energy-braided river with sandy gravelly three-dimensional dunes after Weckwerth (2010, 2013); p1-p3-pradolinas 1-3]

M1/B1 in Fig. 14) were characterized by channel depth up to $1 \mathrm{~m}$, a high Froude number (greater than 0.4 ) and high flow velocity (greater than $0.9 \mathrm{~ms}^{-1}$ ). Apart from this, conditions of shallow water flow in meandering channels (lithotype M1) become similar to the conditions characteristic of shallow-braided rivers with the dominance of the upper plane bed (lithotype B1; cf. Dreyer 1993). Moreover, the increasing flow depth in meandering rivers, together with increasing their sinuosity index (SN from 1.25 up to 1.5 ), were responsible for decreasing the Froude number from $0.5-0.6$ to $0.3-0.4$ (Figs. 10, 11, 14). Increasing median grain diameter of the channel deposits in the case of the lithotype M1 (e.g., fluvial succession at the Chobielin site) reflects cumulative effects over successive cycles of 
climate changes (cf. Busschers et al. 2007; Van Balen et al. 2010), between Dansgaard-Oeschger cycles D/O8 and D/ O5 (Rahmstorf 2003). In turn, this may have resulted in the seasonal increase in the channel aggradation rate of coarser sediments (Van Huissteden and Kasse 2001; Van Huissteden et al. 2001). Similar periodic floods are typical of modern rivers in the polar and sub-polar regions (Vandenberghe 2001).

Based on the thickness of the lithotypes M1 and B1 in relation to the time of their accumulation in the TSB, it can be assumed that the rate of channel deposition occurring between 28 and $24 \mathrm{ka}$ ago (between $\mathrm{D} / \mathrm{O} 4$ and $\mathrm{D} / \mathrm{O} 2$ ) was higher than 40-30 ka ago (between D/O8 and D/O5). Its cause, despite the lack of meltwater feeding, may have been an increase in the efficiency of surface runoff affected by the expansion of continuous permafrost (Renssen and Vandenberghe 2003; Buschers et al. 2005, 2007). These climate conditions in the area of the Torun Basin is proven by wedge casts filled with well-sorted sands at $27 \mathrm{ka}$ ago (Drozdowski and Fedorowicz 1987; Drozdowski and Szupryczyński 1987).

Repetitive climate cooling at the beginning of $\mathrm{H} 3$ event ( $30 \mathrm{ka} \mathrm{ago})$ and $\mathrm{H} 2$ event ( $24 \mathrm{ka}$ ago) (Bond et al. 1999; Hemming 2004; Peck et al. 2007) caused changes in the paleoenvironmental conditions of river catchments. The hydraulic parameters of meandering rivers (lithotype M1) and shallow-braided rivers (lithotype B1) got similar to the conditions enabling threshold changes in the riverbed morphology (a.o. Schumm 1979). They consisted in decreasing the water flow velocity, the reduction of both hydraulic gradient and the Froude number, as well as in increasing the diameter of transported particles and the channel aggradation rate (Figs. 13, 14). The consequence was a river pattern transformation from meandering and shallow-braided(lithotypes M1 and B1) to a braided river style with unit bars (lithotype B2; Figs. 14, 15). This process was initiated by humpback and two-dimensional dune development (e.g., Rozwarzyn site; Fig. 8).

\section{Braided rivers with unit and compound bars}

The lithotypes B2 and B3 form the upper members of the Weichselian fluvial formations. These lithotypes are related to the streams which were fed by meltwaters flowing from the north and precipitation-dependent rivers flowing from the south (Weckwerth and Chabowski 2013). Thus, lithotypes B2 and B3 represent two stages of the icemarginal valley development (pradolinas 1 and 2; Fig. 15) during $\mathrm{H} 3$ and $\mathrm{H} 2$ events (pradolinas 1 and 2, respectively) which differ in relation to the lithological features.

The first stage began with the deposition of the lithotype B2. This corresponded to the transformations of the river channel pattern from meandering (lithotype M1) and shallow-braided- (lithotype B1) into the sand-bed-braided river dominated by unit bars at the beginning of $\mathrm{H} 3$ and $\mathrm{H} 2$ events (cycles $\mathrm{M} 1 \rightarrow \mathrm{B} 2$ and $\mathrm{B} 1 \rightarrow \mathrm{B} 2$, respectively; Figs. 14, 15). These transformations were manifested by decreasing flow velocity (settled the low Froude number), linked to the energy losses associated with bedform roughness and with the transportation of coarser particles supplied to the Torun Basin by sediment-laden meltwater from the north (Figs. 10, 11, 12, 13, 14).

The beginning of the second stage of the ice-marginal valley development (during $\mathrm{H} 2$ event, pradolina 2) coincided with unit bar amalgamation which resulted in the development of compound bars typical for the lithotype B3 (Figs. 14, 15). These macroforms constituted sand shoals within braided river channels. The water flows showed a similar depth range during the deposition of the lithotypes B2 and B3, although the flow velocity was generally greater in rivers of lithotype B3 (Figs. 11, 14), for which the energy of sedimentary environment was more stable than during the deposition of lithotype B2. Therefore, the lithotype B2 represents a transitional phase in the evolution of the sandbed-braided river morphology characterized by two- and three-dimensional dunes and unit bar development.

Deposition of lithotypes B2 and B3 (which was related to the increase of the channel aggradation rate) took place 1-2 thousand years before every ice sheet advance into the Torun Basin, during the development of pradolinas 1 and 2 (Figs. 14, 15). Fluvial lithotypes succession (B2 $\rightarrow$ B3) was deposited during the middle Weichselian and indicates the relatively stable conditions of water flow only before the LGM (area B3 in Figs. 14, 15). Therefore, the development of compound bars is a mature and finale stage of the sandbed-braided river evolution in fluvial cycle. Fluvial successions accumulated in the Torun-Eberswalde ice-marginal valley (pradolina 3) during Pomeranian phase indicate braided river environment which varied under the terms of morphology and flow energy (Fig. 15; Weckwerth 2010, 2013; Pisarska-Jamroży 2015).

River channel pattern transformations which correspond to the fluvial lithotype sequences $\mathrm{M} 1 / \mathrm{B} 1 \rightarrow \mathrm{B} 2$ and $\mathrm{B} 2 \rightarrow \mathrm{B} 3$, occurred 30 and $24 \mathrm{ka}$ ago in the area of the Torun Basin. Fluvial transformation proceeded in Central Poland and in the Southern North-Sea Basin at roughly the same time (Rotnicki 1987; Turkowska 1995; Huisink 1997, 2000; Mol 1997; Buschers et al. 2005, 2007; Cordier et al. 2006; Zieliński 2007). Their causes were related to the glacio-isostacy and climate cooling, which resulted in the development of continuous permafrost, in conditions of which increased the sediment supply into rivers in coincidence with particle coarseness in fluvial succession (cf. Huijzer and Vandenberghe 1998; Renssen and Vandenberghe 2003; Van Huissteden et al. 2001). Moreover, one of the main reasons for the transformation of the river channel morphology in the Torun 
Basin was river regime changes from precipitation-related to glacial which was associated with the two ice-marginal valley development before LGM (Weckwerth and Chabowski 2013). In these valleys, the high rate of fluvial accumulation (deposition of lithotypes B2 and B3) was dependent on the significant sediment load in meltwater streams which fed the Toruń Basin.

\section{Conclusions}

The results of the sedimentological research of the Weichselian fluvial deposits in the Torun Basin allowed the model of fluvial sedimentation to be recognized during successive phases of Weichselian ice sheet advances and retreats as a result of climate fluctuations. Sediments of sand-bed rivers are represented by four fluvial lithotypes which belong to two groups, the first of which (1) represents the high-energy meandering and shallow-braided rivers with upper plane bed (lithotypes $\mathrm{M} 1$ and $\mathrm{B} 1$-rivers of the precipitation-related regime) evolved during D/O8-5 and D/O4-2 cycles. The second group (2) corresponds to the braided rivers with unit and compound bars (lithotypes B2, B3-mainly rivers of the glacial regime) which existed at the time of the $\mathrm{H} 3$ and $\mathrm{H} 2$ events.

Stable conditions for the channel deposition were characteristic of rivers with different flow regimes and riverbed morphology. They were close to the upper flow regime for the lithotype M1 (ephemeral meandering river) and lithotype B1 (shallow braided and flat-bottomed river), while for the lithotype B3 (sand-bed braided river with compound bars) - to the conditions of the lower flow regime. Lithotype B2 represents the transitional phase in the evolution of the riverbed morphology, which corresponds to the sand-bedbraided river dominated by unit bars.

River channel pattern transformations are related to the changes of fluvial lithotypes $(\mathrm{M} 1 / \mathrm{B} 1 \rightarrow \mathrm{B} 2$ and $\mathrm{B} 2 \rightarrow \mathrm{B} 3)$ in Weichselian fluvial successions. It follows that the fluvial deposition that occurred as a result of the development of compound bars (lithotype B3), is a mature stage of the sandbed-braided river development in the fluvial cycle. Transformations of the river channels during the Weichselian glaciation were caused mainly by the climatically related changes in the river regime and intensity of the surface runoff.

Acknowledgements The Author would like to thank Tom van Loon, Kim M. Cohen, Tomasz Zieliński and Leszek Marks for their helpful and valuable comments that improved the quality of the paper. The work was financially supported in part by the Grant of the National Science Center-research project no. 2013/09/B/ST10/00031.

Open Access This article is distributed under the terms of the Creative Commons Attribution 4.0 International License (http:// creativecommons.org/licenses/by/4.0/), which permits unrestricted use, distribution, and reproduction in any medium, provided you give appropriate credit to the original author(s) and the source, provide a link to the Creative Commons license, and indicate if changes were made.

\section{References}

Alexander J, Bridge JS, Cheelà RJ, Leclair SF (2001) Bedforms and associated sedimentary structures formed under supercritical water flows over aggrading sand beds. Sedimentology 48:133-152

Allen JRL (1982) Sedimentary structures, their character and physical basis. V. 1. Dev Sedimentol 30:1-593

Allen JRL (1983) Studies in fluviatile sedimentation: bars, bar complexes and sandstone sheets (low-sinuosity braided streams) in the Brownstones (L. Devonian), Welsh Borders. Sediment Geol 33:237-293

Allen JRL, Leeder MR (1980) Criteria for instability of upper stage plane beds. Sedimentology 27:209-217

Anisimov O, Vandenberghe J, Lobanov V, Kondratiev A (2008) Predicting changes in alluvial channel patterns in North-European Russia under conditions of global warming. Geomorphology 98:262-274

Ashley GM (1990) Classification of large scale subaqueous bedforms: a new look at an old problem. J Sediment Petrol 60:160-172

Ashworth PJ, Best JL, Roden JE, Bristow CS, Klaassen GJ (2000) Morphological evolution and dynamics of a large, sand braid-bar, Jamuna River, Bangladesh. Sedimentology 47:533-555

Ashworth PJ, Sambrook Smith GH, Best JL, Bridge JS, Lane SN, Lunt IA, Reesink AJH, Simpson CJ, Thomas RE (2011) Evolution and sedimentology of a channel fill in the sandy braided South Saskatchewan river and its comparison to the deposits of an adjacent compound bar. Sedimentology 58:1860-1883

Baas JH, Best JL (2002) Turbulence modulation in clay-rich sedimentladen flows and some implications for sediment deposition. J Sediment Res 72:336-340

Babiński Z (1992) Współczesne procesy korytowe dolnej Wisły. Prace Geograficzne IGiPZ PAN 157:1-171

Best JL (2005) The fluid dynamics of river dunes: a review and some future research directions. J Geophisical Res 110:F04S02. doi:1 0.1029/2004JF000218

Best JL, Bridge J (1992) The morphology and dynamics of low amplitude bedwaves upon upper stage plane bed and preservation of planar laminae. Sedimentology 39:737-752

Best JL, Ashworth PJ, Bristow CS, Roden JE (2003) Three-dimensional sedimentary architecture of a large, midchannel sand braid bar, Jamuna river, Bangladesh. J Sediment Res 73:516-530

Blažauskas N, Jurgaitis A, Šinkūnas P (2007) Patterns of late pleistocene proglacial fluvial sedimentation in the SE Lithuanian plain. Sediment Geol 193:193-201

Blodgett KH, Stanley KO (1980) Stratification, bedforms and discharge relations of the braided Platte river system, Nebraska. J Sediment Petrol 50:139-148

Bond GC, Showers W, Elliot M, Evans M, Lotti R, Hajdas I, Bonani G, Johnson S (1999) The North Atlantic's 1-2 kyr climate rhythm: relation to Heinrich events, Dansgaard/Oeschger cycles and the Little Ice Age. In: Clark PU, Webb RS, Keigwin LD (eds) Mechanisms of global climate change at millennial time scales. Geoph Monograph Series, vol 112, pp 35-58

Bridge JS (1985) Paleochannel patterns inferred from alluvial deposits: a critical evaluation. J Sediment Petrol 55:579-589 
Bridge JS (1993) The interaction between channel geometry, water flow, sediment transport and deposition in braided rivers. In: Best JL, Bristow CS (eds) Braided rivers. Special Publication, vol 75, Geological Society, London, pp 13-71

Bridge JS (2003) Rivers and floodplains: forms, processes, and sedimentary record. Blackwell, Oxford

Bridge JS, Best JL (1988) Flow, sediment transport and bedform dynamics over the transition from dunes to upper stage plane beds. Sedimentology 35:753-764

Bridge JS, Lunt IA (2006) Depositional models of Braided rivers. In: Sambrook Smith GH, Best JL, Bristow CS, Petts GE (eds) Braided rivers: process, deposits, ecology and management (special publication 36 of the IAS). Wiley-Blackwell, Malden-Oxford-Carlton

Bridge JS, Smith ND, Trent F, Gabel SL, Bernstein P (1986) Sedimentology and morphology of a low-sinuosity river: Calamus river, Nebraska Sand Hills. Sedimentology 33:851-870

Brykczyński M (1986) O głównych kierunkach rozwoju sieci rzecznej Niżu Polskiego w czwartorzędzie. Przegląd Geograficzny 58:411-440

Busschers FS, Weerts HJT, Wallinga J, Kasse C, Cleveringa P, De Wolf H, Cohen KM (2005) Sedimentary architecture and optical dating of Middle and Late Pleistocene Rhine-Meuse deposits-fluvial response to climate change, sea-level fluctuation and glaciation. Neth J Geosci 84:25-41

Busschers FS, Kasse C, Van Balen RT, Vandenberghe J, Cohen KM, Weerts HJT, Wallinga J, Johns C, Cleveringa P, Bunnik FPM (2007) Late Pleistocene evolution of the Rhine in the southern North-Sea Basin: imprints of climate change, sea-level oscillations and glacio-isostacy. Quat Sci Rev 26:3216-3248

Busschers FS, Van Balen RT, Cohen KM, Kasse C, Weerts HJT, Wallinga J, Bunnik FPM (2008) Response of the Rhine-Meuse fluvial system to Saalian ice-sheet dynamics. Boreas 37:377-398

Cant DJ, Walker RG (1978) Fluvial processes and facies sequences in the sandy braided South Saskatchewan river, Canada. Sedimentology 25:625-648

Cheel RJ (1990a) Flow, sediment transport and bed dynamics over the transition from dunes to upper-stage plane beds: implications for the formation of planar laminae. Sedimentology 37:549-553

Cheel RJ (1990b) Horizontal lamination and the sequence of bed phase and stratification under upper flow-regime conditions. Sedimentology 37:517-529

Cordier S, Harmand D, Beiner M (2006) Fluvial system response to Middle and Upper Pleistocene climate change in the Meurthe and Moselle valleys (Eastern Paris Basin and Rhenish Massif). Quat Sci Rev 25:1460-1474

Crowley KD (1983) Large scale bed configurations (macroforms), Platte river basin, Colorado and Nebraska: primary structures and formative processes. Geol Soc Am Bull 94:117-133

Dade WB (2000) Grain size, sediment transport and alluvial channel pattern. Geomorphology 35:119-126

Dade WB, Friend PF (1998) Grain size, sediment-transport regime and channel slope in alluvial rivers. J Geol 106:661-675

Dey S (2014) Fluvial hydrodynamics: hydrodynamic and sediment transport phenomena. Springer, Berlin, Heidelberg

Drozdowski E, Fedorowicz S (1987) Stratigraphy of Vistulian glaciogenic deposits and corresponding thermoluminescence dates in the lower Vistula region. Boreas 16:139-153

Duller RA, Mountney NP, Russell AJ, Cassidy NC (2008) Architectural analysis of a volcaniclastic jökulhlaup deposit, southern Iceland: sedimentary evidence for supercritical flow. Sedimentology 55:939-964

Erkens G, Dambeck R, Volleberg KP, Bouman MTIJ, Bos JAA, Cohen KM, Wallinga J, Hoek WZ (2009) Fluvial terrace formation in the northern Upper Rhine Graben during the last 20,000 years as a result of allogenic controls and autogenic evolution. Geomorphology 103:476-495

Eyles N, Eyles CH, Miall AD (1983) Lithofacies types and vertical profile models; an alternative approach to the description and environmental interpretation of glacial diamict and diamicite sequences. Sedimentology 30:393-410

Farrell KM (1987) Sedimentology and facies architecture of overbank deposits of the Mississippi river, False river region, Louisiana. In: Ethridge FG, Flores RM, Harvey MD (eds) Recent developments in fluvial sedimentology, Society of Economic Paleontologists, Special publication, vol 39, Tulsa, Oklahoma, pp 111-120

Fielding CR (2006) Upper flow regime sheets, lenses and scour fills: extending the range of architectural elements for fluvial sediment bodies. Sediment Geol 190:227-240

Folk RL, Ward WC (1957) Brazos river bar: a study in the significance of grain size parameters. J Sediment Petrol 27:3-26

Fourrière A, Claudin P, Andreotti B (2010) Bedforms in a turbulent stream: formation of ripples by primary linear instability and of dunes by nonlinear pattern coarsening. J Fluid Mech 649:287-328

Frings RM (2008) Downstream fining in large sand-bed rivers. Earth Sci Rev 87:39-60

Galon R (1961) Morphology of the Noteć-Warta (or Torun-Eberswalde) ice marginal streamway. Prace Geogr IGiPZ PAN, 29

Gorrell G, Shaw J (1991) Deposition in an esker, bead and fan complex, Lenark, Ontario, Canada. Sediment Geol 72:285-314

Hemming SR (2004) Heinrich events: massive late Pleistocene detritus layers of the North Atlantic and their global climate imprint. Rev Geophys. doi:10.1029/2003RG000128

Holbrook J, Schumm SA (1999) Geomorphic and sedimentary response of rivers to tectonic deformation: a brief review and critique of a tool for recognizing subtle epeirogenic deformation in modern and ancient settings. Tectonophysics 305:287-306

Houben P (2003) Spatio-temporally variable response of fluvial systems to Late Pleistocene climate change: a case study from central Germany. Quat Sci Rev 22:2125-2140

Huijzer B, Vandenberghe J (1998) Climatic reconstruction of the Weichselian Pleniglacial in northwestern and central Europe. J Quat Sci 13:391-417

Huisink M (1997) Late-glacial sedimentological and morphological changes in a lowland river in response to climatic change: the Maas, southern Netherlands. J Quat Sci 12:209-223

Huisink M (2000) Changing river styles in response to Weichselian climate changes in the Vecht valley, eastern Netherlands. Sediment Geol 133:115-134

Janssens MM, Kasse C, Bohncke SJP, Greaves H, Cohen KM, Wallinga J, Hoek WZ (2012) Climate-driven fluvial development and valley abandonment at the last glacial-interglacial transition (Oude IJssel-Rhine, Germany). Geologie en Mijnbouw/ Netherlands. J Geosci 91:37-62

Julien PY (2002) River mechanics. Cambridge University Press, Cambridge

Julien PY, Raslan Y (1998) Upper-regime plane bed. J Hydraul Eng 124:1086-1096

Julien PY, Wargadalam J (1995) Alluvial channel geometry: theory and applications. J Hydraul Eng 121:312-325

Karim F (1995) Bed configuration and hydraulic resistance in alluvial-channel flows. J Hydraul Eng 121:15-25

Kasse C, Bohncke S, Vandenberghe J (1995) Fluvial periglacial environments, climate and vegetation during the Middle Weichselian with special reference to the Hengelo Interstadial. Mededelingen Rijks Geologische Dienst 52:387-413

Kasse C, Hoek WZ, Bohncke SJP, Konert M, Weijers JWH, Cassee ML, Van der Zee RM (2005) Late Glacial fluvial response of 
the Niers-Rhine (western Germany) to climate and vegetation change. J Quaternary Sci 20:377-394

Kleinhans GK, Van den Berg JH (2011) River channel and bar patterns explained and predicted by an empirical and a physicsbased method. Earth Surf Process Landf 36:721-738

Knighton D (1984) Fluvial forms and processes. E. Arnold, London Kostaschuk RA (2000) A field study of turbulence and sediment dynamics over subaqueous dunes with flow separation. Sedimentology 47:519-531

Kostaschuk RA, Villard PV (1996) Flow and sediment transport over large subaqueous dunes: Fraser River, Canada. Sedimentology 43:849-863

Kostaschuk R, Shugar D, Best J, Parsons D, Lane S, Hardy R, Orfeo O (2009) Suspended sediment transport and deposition over a dune: Río Paraná, Argentina. Earth Surf Processes Landf 34:1605-1611

Kozarski S (1983) River channel changes in the middle reach of the Warta valley, Great Poland lowland. Quat Stud Pol 4:159-169

Krzyszkowski D (1996) Climatic control on Quaternary fluvial sedimentation in the Kleszczów Graben, central Poland. Quat Sci Rev 15:315-333

Lang J, Winsemann J (2013) Lateral and vertical facies relationships of bedforms deposited by aggrading supercritical flows: from cyclic steps to humpback dunes. Sediment Geol 296:36-54

Langbein WB, Leopold LB (1966) River meanders-theory of minimum variance. U.S. Geological Survey, Professional Paper, 422-H, US Government Printing Office, Washington

Leclair SF, Bridge JS (2001) Quantitative interpretation of sedimentary structures formed by river dunes. J Sediment Res 71:713-716

Leeder MR (1973) Fluviatile fining-upward cycles and the magnitude of palaeochannels. Geol Mag 110:265-276

Leopold LB (1964) Quasi-equilibrium states in channel morphology. Am J Sci 262:782-794

Leopold LB, Wolman MG, Miller JP (1964) Fluvial processes in geomorphology. W. H. Freeman and Company, San Francisco

Makowska A (1980) Late Eemian with preglacial and glacial part of Vistulian Glaciation in Lower Vistula Region. Quat Stud Pol 2:37-56

Marks L (2005) Pleistocene river systems in the southern peribaltic area as indication of interglacial sea level changes in the Baltic Basin. Quat Int 130:43-48

Marks L (2012) Timing of the Late Vistulian (Weichselian) glacial phases in Poland. Quat Sci Rev 44:81-88

Marks L, Ber A, Lindner L (2014) Zasady polskiej klasyfikacji i terminologii stratygraficznej czwartorzędu. Polska Akademia Nauk, Komitet Badań Czwartorzędu, Warszawa

McCabe PJ (1977) Deep distributary channels and giant bedforms in the Upper Carboniferous of the central Pennines, northern England. Sedimentology 24:271-290

McKee ED, Crosby EJ, Berryhill HL Jr (1967) Flood deposits, Bijou Creek, Colorado, June 1965. J Sediment Petrol 37:829-851

Meinsen J, Winsemann J, Roskosch J, Brandes C, Frechen M, Dultz S, Böttcher J (2014) Climate control on the evolution of Late Pleistocene alluvial-fan and aeolian sand-sheet systems in NW Germany. Boreas 43:42-66

Miall AD (1976) Palaeocurrent and palaeohydrologic analysis of some vertical profiles through a Cretaceous braided stream deposit, Banks Island, Arctic Canada. Sedimentology 23:459-483

Miall AD (1978) Lithofacies types and vertical profile models in braided rivers: a summary. In: Miall AD (ed) Fluvial Sedimentology, vol 5. Can. Soc. Petrol. Geol. Mem., Calgary, pp 597-604

Miall AD (1985) Architectural-element analysis: a new method of facies analysis applied to fluvial deposits. Earth Sci Rev 22:261-308
Miall AD (1993) The architecture of fluvial deltaic sequences in the Upper Mesaverde Group (Upper Cretaceous), Book Cliffs, Utah. In: Best JL, Bristow CS (eds) Braided rivers. Special Publication, vol 75. Geological Society, London, pp 305-332

Miall AD (1994) Reconstructing fluvial macroform architecture from two-dimensional outcrops; examples from the Castlegate Sandstone, Book Cliffs, Utah. J Sediment Res 64:146-158

Miall AD (2006) The geology of fluvial deposits. Sedimentary facies, basin analysis, and petroleum geology. Springer, Berlin

Miall AD, Jones BG (2003) Fluvial architecture of the Hawkesbury Sandstone (Triassic), near Sydney, Australia. J Sediment Res 73:531-545

Mohrig D, Smith JD (1996) Predicting the migration of dunes. Water Resour Res 32:3207-3217

Mohrig D, Heller PL, Paola C, Lyons WJ (2000) Interpreting avulsion process from ancient alluvial sequences: Guadalope-Matarranya system (northern Spain) and Wasatch Formation (western Colorado). GSA Bull 112:1787-1803

Mol J (1997) Fluvial response to Weichselian climate changes in the Niederlausitz (Germany). J Quat Sci 12:43-60

Molewski P (2007) Neotektoniczne i glacidynamiczne uwarunkowania wykształcenia plejstocenu Wysoczyzny Kujawskiej. Wyd. Nauk. UMK, Toruń

Murray AS, Wintle AG (2000) Luminescence dating of quartz using an improved single-aliquot regenerative-dose protocol. Radiat Meas 32:57-73

Noryśkiewicz B (1978) Interglacjał eemski w Nakle nad Notecią. Acta Palaeobotanica 19:67-112

Olsen H (1988) The architecture of a sandy braided-meandering river system: an example from the Lower Triassic Solling Formation (M. Buntsandstein) in W-Germany. Geol Rundsch 77:797-814

Olsen H (1989) Sandstone body structures and ephemeral stream processes in the Dinosaur Canyon Member, Moenave Formation (Lower Jurassic), Utah, USA. Sediment Geol 61:207-221

Paola C (2000) Quantitative models of filling. Sedimentology 47:121-178

Paola C, Borgman L (1991) Reconstructing random topography from preserved stratification. Sedimentology 38:553-565

Paola C, Wiele SM, Reinhart MA (1989) Upper-regime parallel lamination as the result of turbulent sediment transport and lowamplitude bed forms. Sedimentology 36:47-59

Paola C, Heller PL, Angevine CL (1992) The larges-cale dynamics of grain-size variation in alluvial basins, 1: theory. Basin Res 4:73-90

Peck VL, Hall IR, Zahn R, Grousset F, Hemming SR, Scourse JD (2007) The relationship of Heinrich events and their European precursors over the past $60 \mathrm{ka}$ BP: a multi-proxy ice-rafted debris provenance study in the North East Atlantic. Quat Sci Rev 26:862-875

Pisarska-Jamroży M (2015) Factors controlling sedimentation in the Toruń-Eberswalde ice-marginal valley during the Pomeranian phase of Weichselian glaciation: an overview. Geologos 21:1-29

Pisarska-Jamroży M, Van Loon AJ, Woronko B, Sternal B (2015) Heavy-mineral analysis as a tool to trace the source areas of sediments in an ice-marginal valley, with an example from the Pleistocene in NW Poland. Neth J Geosci 94:185-200

Prent M, Hickin EJ (2001) Annual regime of bedforms, roughness and flow-resistance, Lillooet River, British Columbia. Geomorphology $41: 369-390$

Rahmstorf S (2003) Timing of abrupt climate change: A precise clock. Geophys Res Lett 30:1510-1514

Renssen H, Vandenberghe J (2003) Investigation of the relationship between permafrost distribution in NW Europe and extensive winter sea-ice cover in the North Atlantic Ocean during the cold phases of the Last Glaciation. Quat Sci Rev 22:209-223 
Rotnicki K (1987) Main phases of erosion and accumulation in the middle and lower Prosna valley in the Last Glacial-Interglacial Phase. Quat Stud Pol 9:73-83

Russell HAJ, Sharpe DR, Bajc AF (2007) Sedimentary signatures of the waterloo moraine, Ontario, Canada. In: Hambrey MJ, Christoffersen P, Glasser NF, Hubbard B (eds) Glacial sedimentary processes and products, special publication of international association of sedimentologists, vol 39. Blackwell, Oxford, pp 85-108

Sambrook Smith GH, Ashworth PJ, Best JL, Woodward J, Simpson CJ (2006) The sedimentology and alluvial architecture of the sandy braided South Saskatchewan River, Canada. Sedimentology 53:413-434

Saunderson HC, Jopling AU (1980) Palaeohydraulics of a tabular, cross-stratified sand in the Brampton esker. Ontario Sed Geol 25:169-188

Schumm SA (1977) The fluvial system. John Wiley, New York

Schumm SA (1979) Geomorphic thresholds: the concept and its applications. Trans Inst Br Geogr 4:485-515

Schumm SA (1985) Patterns of alluvial rivers. Annu Rev Earth Planet Sci 13:5-27

Schumm SA, Brakenridge GR (1987) River responses. In: Ruddiman WF, Wright HE Jr (eds) North America and adjacent oceans during the last deglaciation: the geology of North America, vol K-3. Geological Society of America, Boulder, Colorado, pp 221-240

Siddall M, Bard E, Rohling EJ, Hemleben C (2006) Sea-level reversal during Termination II. Geology 34:817-820

Simons DB, Richardson EV (1962) Resistance to flow in alluvial channels. Am Soc Civil Eng Trans 127:927-954

Skelly RL, Bristow CS, Ethridge FG (2003) Architecture of channelbelt deposits in an aggrading shallow sandbed braided river: the lower Niobrara River, northeast Nebraska. Sediment Geol 158:249-270

Sly PG, Thomas RL, Pelletier BR (1983) Interpretation of moment measures derived from water-lain sediments. Sedimentology 30:219-233

Smith ND (1978) Some comments on terminology for bars in shallow rivers. In: Miall AD (ed) Fluvial Sedimentology, vol 5. Can. Soc. Petrol. Geol Mem., Calgary, pp 85-88

Southard JB (1991) Experimental determination of bedform stability. Annu Rev Earth Planet Sci 19:423-455

Southard JB, Boguchwal LA (1990) Bed configurations in steady unidirectional water flows. Part 2. Synthesis of flume data. J Sediment Petrol 60:658-679

Starkel L, Gębica P, Superson J (2007) Last glacial-interglacial cycle in the evolution of river valleys in southern and central Poland. Quat Sci Rev 26:2924-2936

Stear WM (1983) Morphological characteristics of ephemeral stream channel and overbank splay sandstone bodies in the permian lower beaufort group, Karoo Basin, South Africa. In: Collinson JD, Lewin J (eds) Modern and ancient fluvial systems: International association of sedimentologists. Special Publication, vol 6. Blackwell Science, Oxford, pp 405-420

Thorne CR (1997) Channel types and the morphological classification. In: Thorne CR, Hey RD, Newson MD (eds) Applied fluvial geomorphology for river engineering and management. Wiley, Chichester, pp 175-222

Tomczak A (1987) Evolution of the Vistula valley in the Torun Basin in the Late Glacial and Holocene. In: Starkel L (ed) Evolution of the Vistula river valley during the last 15000 years. Geographical studies, Special issue 4, IGiPZ PAN, pp 207-232

Tucker ME (2003) Sedimentary rocks in the field. John Wiley, Chichester

Tunbridge IP (1981) Sandy high-energy flood sedimentation-some criteria for recognition, with an example from the Devonian of SW England. Sediment Geol 28:79-96
Tunbridge IP (1984) Facies model for a sandy ephemeral stream and playa complex; the Devonian Trentishoe formation of North Devon, United Kingdom. Sedimentology 31:697-715

Turkowska K (1995) Recognition of the valley evolution during the Pleistocene-Holocene transition in non-glaciated regions of the Polish Lowland. Biul Peryglac 34:209-227

Uniejewska M, Nosek M (1992) Objaśnienia do Szczegółowej Mapy Geologicznej Polski w skali 1:50 000 ark. Łabiszyn. PIG, Warszawa

Van Huissteden J, Kasse C (2001) Detection of rapid climate change in Last Glacial fluvial successions in The Netherlands. Glob Planet Change 28:319-339

Van Huissteden J, Gibbard PL, Briant RM (2001) Periglacial fuvial systems in northwest Europe during marine isotope stages 4 and 3. Quat Int 79:75-88

Van Balen RT, Busschers FS, Tucker GE (2010) Modeling the response of the Rhine-Meuse fluvial system to Late Pleistocene climate change. Geomorphology 114:440-452

Van den Berg JH (1995) Prediction of alluvial channel pattern of perennial rivers. Geomorphology 12:259-279

Van den Berg JH, Bledsoe BP (2003) Comment on Lewin and Brewer (2001), "Predicting channel patterns', Geomorphology 40:329339 (Geomorphology 53:333-337)

Vandenberghe J (1993) Changing fluvial processes under changing periglacial conditions. Zeits für Geomorph NF Suppl Bd 88:17-28

Vandenberghe J (1995) Timescales, climate and river development. Quat Sci Rev 14:631-638

Vandenberghe J (2001) A typology of Pleistocene cold-based rivers. Quat Int 79:111-121

Vandenberghe $\mathbf{J}$ (2002) The relation between climate and river processes, landforms and deposits during the Quaternary. Quat Int 91:17-23

Vandenberghe J (2003) Climate forcing of fluvial system development: an evolution of ideas. Quat Sci Rev 22:2053-2060

Vandenberghe J, Kasse C, Bohncke SJP, Kozarski S (1994) Climaterelated river activity at the Weichselian-Holocene transition: a comparative study of the Warta and Maas rivers. Terra Nova 6:476-485

Weckwerth P (2010) Evolution of the Torun Basin in the Late Weichselian. Landf Anal 14:57-84

Weckwerth P (2011) Palaeoslopes of Weichselian sand-bed braided rivers in the Torun Basin (Poland): results of palaeohydraulic analysis. Geologos 17:227-238

Weckwerth P (2013) Ewolucja fluwialnych systemów depozycyjnych i jej uwarunkowania paleośrodowiskowe w Kotlinie Toruńskiej podczas zlodowacenia wisły. NCU Press, Toruń

Weckwerth P, Chabowski M (2013) Heavy minerals as a tool to reconstruct river activity during the Weichselian glaciation (Toruń Basin, Poland). Geologos 19:25-46

Weckwerth P, Pisarska-Jamroży M (2015) Periglacial and fluvial factors controlling the sedimentation of pleistocene breccia in NW Poland. Geogr Ann Ser A Phys Geogr 97(2):415-430

Weckwerth P, Przegiętka K, Chruścińska A, Woronko B, Oczkowski HL (2011) Age and sedimentological features of fluvial series in the Toruń Basin and the Drwęca Valley (Poland). Geochronometria 38:397-412

Weckwerth P, Przegiętka K, Chruścińska A, Pisarska-Jamroży M (2013) The relation between optical bleaching and sedimentological features of fluvial deposits in the Torun Basin (Poland). Geol Q 57:31-44

Wentworth CK (1922) A scale of grade and class terms for clastic sediments. J Geol 30:377-392

Williams GE (1971) Flood deposits of the sand-bed ephemeral streams of central Australia. Sedimentology 17:1-40 
Williams GP (1983) Paleohydrological methods and some examples from Swedish fluvial environments. I. Cobble and boulder deposits. Geogr Ann 65A:227-243

Winsemann J, Brandes C, Polom U (2011) Response of a proglacial delta to rapid highamplitude lake-level change: an integration of outcrop data and high-resolution shear wave seismic. Basin Res 23:22-52

Wintle AG, Murray AS (2006) A review of quartz optically stimulated luminescence characteristics and their relevance in single-aliquot regeneration dating protocols. Radiat Meas 41:369-391

Wiśniewski E (1990) Evolution of the Vistula Valley. In: Starkel L (ed) Evolution of the Vistula river valley during the last 15000 years, Geographical studies, Special issue 5, IGiPZ PAN, pp 141-146

Woronko B, Pisarska-Jamroży M, Van Loon AJ (2015) Reconstruction of sediment provenance and transport processes from the surface textures of quartz grains from Late Pleistocene sandurs and an ice-marginal valley in NW Poland. Geologos 21:105-115

Wysota W (2002) Stratygrafia i środowiska sedymentacji zlodowacenia wisły w południowej części dolnego Powiśla. UNC Press, Toruń

Wysota W, Lankuaf KR, Molewski P, Szmańda J (1996) Sedymentologia interstadialnej serii rzecznej (Rzęczkowo) zlodowacenia Wisły (Vistulian) odsłoniętej w SW krawędzi Wysoczyzny Che1mińskiej. Acta UNC. Geografia 28:39-63

Wysota W, Molewski P, Sokołowski RJ (2009) Record of the Vistula ice lobe advances in the Late Weichselian glacial sequence in north-central Poland. Quat Int 207:26-41

Zieliński T (1992) Proglacial valley facies of the Silesian Uplandgenetic factors and their sedimentological effects. Geologia Sudetica 26:83-118

Zieliński T (1993) Sandry Polski północno-wschodniej-osady i warunki sedymentacji. Prace Naukowe Uniwersytetu Śląskiego 1398:1-96
Zieliński T (1995) Kod litofacjalny i litogenetyczny - konstrukcja i zastosowanie. In: Mycielska-Dowgiałło E, Rutkowski J (eds) Badania osadów czwartorzędowych. Wybrane metody i interpretacja wyników, WGiSR UW, Warszawa, pp 221-234

Zieliński T (1998) Litofacjalna identyfikacja osadów rzecznych. In: Mycielska-Dowgiałło E (ed) Struktury sedymentacyjne i postsedymentacyjne w osadach czwartorzędowych i ich wartość interpretacyjna, Warszawa, pp 195-257

Zieliński T (2007) The pleistocene climate-controlled fluvial sedimentary record in the Bełchatów mine (central Poland). Sediment Geol 193:203-209

Zieliński T (2014) Sedymentologia. Osady rzek i jezior. Wydawnictwo Naukowe UAM, Poznań

Zieliński T, Goździk J (2001) Palaeoenvironmental interpretation of a Pleistocene alluvial succession in central Poland: sedimentary facies analysis as a tool for palaeoclimatic inferences. Boreas 30:240-253

Zieliński T, Van Loon AJ (1999) Subaerial terminoglacial fans II: a semi-quantitative sedimentological analysis of the middle and distal environment. Geologie en Mijnbouw 78:73-85

Zieliński T, Van Loon AJ (2003) Pleistocene sandur deposits represent braidplains, not alluvial fans. Boreas 32:590-611

Zieliński T, Pisarska-Jamroży M (2012) Jakie cechy litologiczne warto kodować, a jakie nie? Przegląd Geologiczny 60:387-397

Zieliński P, Sokołowski RJ, Woronko B, Jankowski M, Fedorowicz S, Zaleski I, Molodkov A, Weckwerth P (2015) The depositional conditions of the fluvio-aeolian succession during the last climate minimum based on the examples from Poland and NW Ukraine. Quatern Int 386:30-41 